Espacio, Tiempo y Forma, Serie II, Historia Antigua, t. 23, 2010, págs. 307-340

\title{
Los celtíberos y la ubicación de Celtiberia en el relato de la segunda Guerra Púnica, de Tito Livio
}

\author{
Celtiberians and the location of Celtibera in the story second \\ Punic War, of Titus Livius
}

Serafín Olcoz Yanguas y Manuel Medrano Marqués ${ }^{1}$

\begin{abstract}
RESUMEN
La revisión de los textos de Livio nos ha permitido recuperar la visión del estado territorial celtíbero con el que tuvieron que interaccionar cartagineses y romanos, desde su llegada a la península Ibérica en el siglo III a. C. hasta el final de la segunda Guerra Púnica y, por tanto, de la primera Guerra de Roma en Hispania. También nos ha permitido definir mejor el significado que se venía atribuyendo a los conceptos de "celtíberos" $y$ "Celtiberia», haciendo énfasis en su evolución conceptual a lo largo del tiempo.

Destacando el dato del sometimiento del estado celtíbero a Roma en una fecha tan temprana como 217 a. C. así como que la

primera incursión romana en Celtibera acaeció en 207 a. C.

PALABRAS CLAVE:

Estado territorial celtíbero, límites de Celtiberia, cartagineses, segunda guerra púnica, conquista romana.
\end{abstract}

\begin{abstract}
The revision of the texts of Livy has allowed us to recover the vision of the Celtiberian territorial state with which Carthaginians and Romans had had interaction, since its arrival to the Iberian peninsula in the 3rd century BC. until the end of the second Punic War and, therefore, the first War of Rome in Hispania. Also has allowed us to better define the meaning that had been attributed to the concepts of "Celtiberos" and "Celtiberia», emphasizing their conceptual evolution over time.

Highlighting the fact the Celtiberian state was submitted to Rome as soon as 217 a. C. and the first Roman incursion in Celtiberia happened on 207 a. C.

\section{KEYWORDS:}

Celtiberian territorial state, limits of Celtiberia, carthaginian, second Punic war, Roman conquest.
\end{abstract}

\footnotetext{
1 Universidad de Zaragoza. olcoz@unizar.es y medrano@unizar.es
} 


\section{INTRODUCCIÓN}

La definición del marco geográfico correspondiente a Celtiberia parece haber evolucionado con el paso del tiempo y ser su descripción dependiente del autor clásico consultado y de la época a la que se hace referencia en cada caso y contexto ${ }^{2}$. Algo parecido se puede decir acerca del pueblo o de los pueblos a los que los textos clásicos hacen referencia como celtíberos ${ }^{3}$. Sin embargo, tenemos que constatar que en el relato de la segunda Guerra Púnica, Tito Livio parece que tenía una idea concreta de a qué pueblo se refería cuando hablaba de los celtíberos, así como de dónde ubicaba Celtiberia, al menos, en la época del citado contexto bélico. De ahí que nos interese revisar, de forma minuciosa y específica, la información aportada por este autor latino acerca de los celtíberos y de Celtiberia durante el período correspondiente a la segunda Guerra Púnica. Esto es, la información que nos ha transmitido la obra de Livio acerca de la relación que mantuvieron los celtíberos, cuando aún eran casi libres e interaccionaban tanto con los cartagineses como con los romanos, en Hispania y fuera de ella ${ }^{4}$. Todo ello poco antes de que los romanos derrotaran a los cartagineses y de que, después, emprendieran la definitiva conquista de la península Ibérica, Celtiberia incluida.

\section{EL TRATADO DEL EBRO Y DOMINIO CARTAGINÉS EN CELTIBERIA}

En ninguna información conocida hasta ahora acerca de Celtiberia y de los celtíberos, especialmente en la bibliografía publicada últimamente, se menciona su ubicación al norte del río Ebro, más bien parece que este río podría formar parte de su límite septentrional o, en cualquier caso, parece que la mayor parte de su territorio se encontraba al sur del Ebro. Lo que pone de manifiesto la importancia de saber cómo pudo afectar a los celtíberos el hecho de que, en $226^{5}$, romanos y cartagineses acordaran que éstos no llevarían su expansión por la península Ibérica a

2 Estrabón recogió el hecho de que el territorio correspondiente a Celtiberia había evolucionado con el paso del tiempo, aclarando que el historiador griego Polibio afirma que tanto el Anas como el Betis fluyen desde Celtiberia (se hallan separados uno de otro por unos novecientos estadios); pues los celtíberos, como habían acrecentado su poder, hicieron que todos los territorios vecinos recibieran el mismo nombre que ellos, (Estrabón III 2, 11), ocupando un territorio mayor que el que tenían en época del geógrafo griego. Ciprés consideró que la asociación de este dato con Polibio nos sitúa posiblemente en el siglo II, es decir, en pleno proceso de conquista y conocimiento de las regiones del interior peninsular. Aunque, como también señaló Ciprés: no sólo de la obra de Estrabón podemos concluir que Celtiberia fue una realidad cambiante. Una revisión del conjunto de las fuentes, tanto republicanas como de época imperial, así lo confirman. Información que, en parte, hemos corroborado tras constatar los efectos de la expansión de los celtíberos al principio del siglo II a. C. y la consecuente conquista romana de Celtiberia que tuvo como consecuencia el retorno de este territorio a unos límites parecidos a los que había tenido anteriormente, como hemos propuesto recientemente. Ciprés 1993, p. 275-280, Ciprés 2006, pp. 58-60, Gómez 2007, pp. 189-190 y Olcoz y Medrano 2011, en prensa.

3 Burillo presentó un resumido estado de ambas cuestiones. Burillo 2008, pp. 27-36 y 42-70.

4 Seguimos la traducción de Villar para los pasajes de la obra de Tito Livio que citamos. Villar 1993a y 1993b.

5 Todas las fechas citadas en este trabajo son a. C. 
dicha margen izquierda del Ebro 6 , pues, eso querría decir que la frontera norte de los celtíberos pasó a ser también la frontera norte de los cartagineses ${ }^{7}$. Evidentemente, ninguna de las dos potencias mediterráneas debió consultar a los celtíberos cuando ambas decidieron que su futuro y el de otros muchos pueblos quedaban vinculados al de la evolución de los dominios cartagineses en la península lbérica. Aunque esto no quiere decir que, desde que Amílcar Barca desembarcó con su contingente de tropas cartaginesas en la península Ibérica, en 237, ni siquiera que desde la firma del tratado del Ebro en $226^{8}$, todos los territorios, ciudades y pueblos ubicados al sur de este río ya estuvieran bajo el dominio cartaginés y que, además, lo estuvieran de forma voluntaria, ni mucho menos. Por lo que creemos que lo primero que conviene que intentemos dilucidar es en qué estado se encontraban las relaciones entre celtíberos y cartagineses antes de que diera comienzo la segunda Guerra Púnica.

En los preparativos de la conquista cartaginesa de Sagunto, durante el verano de 221, Aníbal preparó la coartada que justificaría su conquista de Sagunto ya que como atacarlos [a los saguntinos] iba a provocar con toda seguridad una reacción armada por parte de los romanos, llevó primero a su ejército al territorio de los ólcades - pueblo éste situado en el territorio de los cartagineses más que bajo su dominio, al otro lado del Ebro- para que pudiese dar la impresión, no de que había atacado a los saguntinos sino de que se había visto arrastrado a esta guerra por la concatenación de los hechos, una vez dominados y anexionados los pueblos circundantes. Asalta y saquea la rica ciudad de Cartala, capital de dicho pueblo; sacudidas por esta amenaza las ciudades más pequeñas se someten a su dominio im-

6 Sánchez (1976, pp. 76, 83-93 y 110) señaló que el tratado tuvo que alcanzarse entre el otoño de 226 y la primavera de 225, poniendo especial énfasis en que en él no debió mencionarse a Sagunto, a pesar de lo recogido, por ejemplo, por Livio XXI 2, 7; 7; 8 y 18, 9, como también señaló Santos (1977, pp. 278-281 y 283).

7 Hernández presentó la arriesgada hipótesis de que la ciudad de Contrebia Leucade (InestrillasAguilar del Río Alhama, La Rioja), situada en la margen derecha del río Alhama que, a su vez, es afluente del Ebro por dicha margen, pudo haber sido anteriormente la ciudad púnica conocida como Akra Leuke y que, tradicionalmente, se viene localizando en Alicante. Para ello y a la luz de los resultados de las excavaciones arqueológicas que allí viene realizando desde hace varias décadas, remontó la fundación de Contrebia Leucade, datada por Taracena en un momento posterior a la campaña de Graco en Celtiberia de 179, a finales del siglo III o a principios del II, vinculando la existencia de unas torres cuadrangulares y compartimentadas con las que tienen origen feno-púnico en la costa mediterránea. Sin embargo, creemos que si los datos arqueológicos relacionan la fundación de Contrebia Leucade, ubicada en la mejor vía de comunicación entre el valle de este río y la meseta del Duero, con uno de los puntos defensivos más importantes de la frontera del dominio cartaginés al sur del Ebro, de ello no se deducen los argumentos expuestos por Hernández para trasladar erróneamente buena parte de los acontecimientos más importantes de la segunda Guerra Púnica, desde la cabecera del río Guadalquivir al valle medio-alto del Ebro, y a la reducción o identificación de Contrebia Leucade con Akra Leuke, etc. Por lo que disentimos completamente de tan arriesgada propuesta, tal como ya hiciera Burillo con anterioridad. Hernández 2004, pp. 69-76, y Burillo 2008, pp. 268 y 279.

8 Del mismo modo que no todos los pueblos ubicados entre la margen izquierda del Ebro y los Pirineos se encontraban bajo el dominio romano, aunque algunos de éstos sí que lo estuvieron, como recogió Livio diciendo que mientras tenían lugar estos acontecimientos en Italia, Gneo Cornelio Escipión, enviado a Hispania con una flota y un ejército, saliendo desde la desembocadura del Ródano y después de bordear los montes Pirineos llegó con la flota a Ampurias, desembarcó allí al ejército y, comenzando por los layetanos, sometió al dominio romano toda la costa hasta el río Ebro, en unos casos renovando los tratados y en otros estableciéndolos por vez primera, Livio XXI 60, 3-4. 
poniéndoseles un tributo. El ejército victorioso y cargado de botín es conducido a Cartagena a los cuarteles de invierno. Allí, repartiendo con generosidad el botín y abonando debidamente las pagas militares atrasadas se aseguró por completo las voluntades de conciudadanos y aliados y a principios de la primavera puso en marcha la guerra contra los vacceos. Sus ciudades de Hermándica y Arbocala fueron tomadas por la fuerza. Arbocala se defendió largo tiempo gracias al valor y al número de sus habitantes. Los fugitivos de Hermándica después de unirse a los exiliados de los ólcades, pueblo dominado el verano anterior, instigan a los carpetanos ${ }^{9}$ y atacando a Aníbal a su regreso de territorio vacceo no lejos del río Tajo, desbarataron la marcha de su ejército cargado con el botín. Aníbal obvió el combate y después de acampar a la orilla del río, una vez que reinó la calma y el silencio en el lado enemigo vadeó el río, levantó una empalizada de forma que los enemigos tuviesen sitio por donde cruzar y decidió atacarlos cuando estuvieran cruzando. Dio orden a la caballería de que atacasen a la columna entorpecida cuando la viesen metida en el agua; los elefantes, pues había cuarenta, los colocó en la orilla. Entre carpetanos y tropas auxiliares de ólcades y vacceos sumaban cien mil, ejército invencible si la lucha se desarrollara en campo abierto... y Aníbal, antes de que se recobrasen sus ánimos de tan tremendo susto, metiéndose en el río en formación al cuadro los obligó a huir de la orilla, y después de arrasar el territorio en cosa de pocos días recibió también la sumisión de los carpetanos. Desde este momento quedaba en poder de los cartagineses todo el territorio del otro lado del Ebro, exceptuando los saguntinos ${ }^{10}$. De lo que se deduce que los celtíberos, cuyo territorio tradicionalmente se ha considerado que quedaba en el valle medio del Ebro ${ }^{11}$, limitando con el curso de este río por el Norte, al Oeste con el territorio de los vacceos, al Suroeste con el de los carpetanos y al Sureste con el de los ólcades ${ }^{12}$, ya estaban

9 Se trata de la primera referencia a una liga de pueblos hispanos que coyunturalmente y con objeto de enfrentarse a un enemigo común, en este caso los cartagineses, realizó Livio. Aunque, más adelante hizo referencia a otras coaliciones similares entre distintos pueblos hispanos que unieron sus fuerzas para combatir a los romanos. Por ejemplo en Livio XXXV 7, 8 y XXXIX 30 y 31, que son dos ocasiones en las que entre los pueblos confederados figuran los celtíberos.

10 Livio se refiere a las márgenes del Ebro según estén más cerca o lejos de Roma, de modo que el territorio de los cartagineses quedaba al otro lado del Ebro.

11 Con excepción de la extraña y cuestionada propuesta de Capalvo para ubicar parte de Celtiberia en Hispania Ulterior que, como señalaron Cyprés y Burillo, parece no haber tenido gran aceptación. De hecho, nosotros mismos rebatimos alguno de sus principales argumentos un poco más adelante. Capalvo 1996, Ciprés 2006, pp. 190 y 192, y Burillo 2006, pp. 40-42.

12 Descripción muy similar a la que hizo Estrabón, refiriéndose al estado de Celtiberia en su época pues ya hace referencia a la provincia Bética, diciendo que después de sobrepasar la ldubeda se haIla de inmediato Celtiberia, muy extensa y desigual. Su mayor parte es escarpada y surcada por ríos; pues a través de su territorio fluyen el Anas, el Tajo y la mayor parte de otros ríos a continuación, que descienden hacia el mar occidental y tienen su origen en Celtiberia, de ellos el Duero fluye por Numancia y Serguncia (el Betis en cambio fluye desde sus fuentes en la Orospeda a través de la Oretania hacia la Bética), (Estrabón III, 4, 12), así como que a continuación de los celtíberos hacia el sur se haIlan los sedetanos, que habitan la cadena montañosa de la Orospeda y el territorio de los alrededores del Sucro hasta Cartago Nova, y los bastetanos y los oretanos casi hasta Malaca, (Estrabón III, 4, 14). En esta descripción se incluyen unos límites meridionales parecidos a los que tuvo Celtiberia antes de la expansión de los celtíberos a principios del siglo II, como recientemente hemos propuesto. Aunque también dejó fuera de Celtiberia los territorios ubicados al norte de la Idubeda que ya estaban muy romanizados tras las guerras civiles. Olcoz y Medrano 2011, en prensa. 
bajo la influencia y el dominio cartaginés antes del $221^{13}$. Pues los celtíberos no figuran entre los pueblos que Aníbal tuvo que dominar antes de retirarse a Cartagena a pasar el invierno del 220 al 219 a. C. para finalizar los preparativos de la conquista de Sagunto ${ }^{14} \mathrm{y}$, tras ésta, los de la de Roma ${ }^{15}$.

\section{REHENES/ALIADOS DE LOS CARTAGINESES Y, DESPUÉS, DE LOS ROMANOS}

La primera referencia explícita de Tito Livio a Celtiberia se produce en el contexto de la campaña transalpina de Aníbal y en un momento en el que su ejército se encontraba ya en la península Itálica, camino de Roma. Forma parte de la arenga que el cartaginés dio a sus tropas ante el inminente enfrentamiento con los romanos que le trataban de cerrar el paso, bajo las órdenes de Publio Cornelio Escipión, en los preámbulos de la batalla del río Tesino, en el valle del río Po, a finales de 218 a. C. En esta ocasión, Aníbal prometió a sus tropas la obtención de recompensas mayores que las que habían obtenido hasta entonces corriendo detrás del ganado de los desolados montes de Lusitania y Celtiberia sin ver ningún pago a tantos trabajos y peligros, (Livio, XXI, 43, 8).

Seguramente, este discurso animó a los cartagineses aunque no sabemos qué tal le tuvieron que sentar estas palabras a las tropas auxiliares que les acompañaban y entre las que había parte que habían sido reclutadas en Lusitania y Celtiberia. Tropas que, al menos, eran de caballería, pues Livio así las citó al señalar que, a principios de 217, los campamentos invernales de los romanos que trataban de hacer frente a esta invasión cartaginesa se veían hostigados por jinetes norteafricanos de Numidia, contando éstos, cuando tenían dificultades, con el apoyo de

13 Deducción que está en consonancia que la relación que hemos comentado que hizo Hernández entre la poliorcética de la ciudad de Contrebia Luecade y su posible fundación de origen feno-púnico y que también tuvo en cuenta Burillo. Hernández 2004, pp. 69-76 y Burillo 2008, p. 279.

14 Durante el asedio de Sagunto, sus desmoralizados habitantes se reanimaron al llegarles la noticia de una súbita expedición de Aníbal contra los oretanos y carpetanos, dos pueblos que, soliviantados por el rigor del llamamiento a filas, habían retenido a los reclutadores haciendo temer una defección, pero que desistieron de un levantamiento armado sorprendidos por la rápida reacción de Aníbal, Livio XXI 11, 13

15 Aníbal completó el dominio sobre los pueblos existentes en la margen izquierda del Ebro una vez que lo cruzó con su ejército, antes de cruzar los Pirineos en su camino hacia Roma, tal como registró Livio, diciendo: Lleno de alegría por esta visión, [Aníbal] hizo que sus tropas cruzaran el Ebro en tres cuerpos enviando por delante unos emisarios para ganarse a base de dádivas los ánimos de los galos por donde tenía que pasar el ejército y para efectuar un reconocimiento de los pasos de los Alpes. Cruzó el Ebro con noventa mil soldados de a pie y doce mil de a caballo. Sometió seguidamente a los ilergetes y barguisos y a los ausetanos y la Lacetania, que está situada en las estribaciones de los montes Pirineos, y le dio a Hannón el mando de toda aquella comarca para mantener bajo su control los desfiladeros que comunican las Hispanias con las Galias. Para mantener la ocupación de la zona le fue entregado a Hannón un destacamento de diez mil soldados de infantería y mil de caballería, Livio XXI 23, 1-4. Además, al recoger la arenga de Aníbal poco antes de llegar a los Alpes, añadió que éste dijo a sus tropas que está sorprendido del pánico que ha invadido de repente sus corazones siempre impávidos; tantos años como llevaban en el ejército venciendo, ya que no habían salido de Hispania hasta que todos los pueblos y las tierras abrazadas por dos mares opuestos fueran de los cartagineses, Livio XXI 30, 2. 
caballería lusitana y celtíbera ${ }^{16}$. Especialmente si esta caballería hispana ${ }^{17}$ no estaba en Italia al servicio de los cartagineses de forma voluntaria y a cambio de ciertos honorarios, esto es, como mercenarios, sino que se encontraban allí forzosamente, para salvaguardar la salud y el bienestar de los rehenes que Aníbal pudo haber tomado en esos territorios como forma de asegurarse sus servicios ${ }^{18}$ y que, como veremos, estaban bajo custodia cartaginesa en Sagunto. Situación acorde con una Celtiberia aún dominada por los cartagineses, más que con la contratación por parte de éstos de mercenarios celtíberos y mucho menos todavía con el supuesto apoyo voluntario de tropas auxiliares celtíberas aliadas.

Relación de dependencia que los celtíberos experimentaron pocos meses después con los romanos que habían desembarcado en la península lbérica, concretamente en Ampurias (Gerona) en 218, ya que pasaron a estar bajo su dominio pues, a pesar de que Celtiberia quedaba lejos de la costa mediterránea y, por tanto, de los acuartelamientos romanos y de los principales escenarios bélicos de la segunda Guerra Púnica, no fueron el único pueblo del interior y de las zonas más alejadas de la península Ibérica que, en 217, se sometieron a los romanos ${ }^{19}$. Pues Livio dejó cons-

16 Livio, XXI, 57, 5.

17 Al igual que Livio, que tiene por costumbre referirse con el genérico de hispanos a las coaliciones en las que interviene más de un pueblo, también usamos el término hispano con dicho significado. No empleando el genérico de ibero que, de un modo parecido empleó Apiano, por ejemplo, ya que éste, no siempre usó ibero de una forma tan genérica y, ala vez tan concreta o bien definida, como hizo Livio con el término hispano ya que, a veces, Apiano citó a iberos y celtíberos, (Apiano VI, 3), por ejemplo, esto es, una referencia genérica y una específica en la misma frase. Cosa que Livio nunca hizo pues éste o bien enumeraba todos los pueblos por su nombre o usaba el genérico hispano para citar la participación conjunta de más de uno de ellos pero nunca mezclando ambas posibilidades como sí hizo Apiano.

18 [En Cartagena (Murcia),] Aníbal, después de pasar revista a las tropas auxiliares de todos los pueblos, marchó a Cádiz y cumplió los votos a Hércules comprometiéndose con otros nuevos para el caso de que todo lo demás saliera bien. A continuación, preocupándose al mismo tiempo de la ofensiva y la defensiva bélica, no fuera a ocurrir que, mientras él se dirigía a Italia por tierra a través de Hispania y de la Galia, quedase África desguarnecida y con el flanco descubierto por la parte de Sicilia para los romanos, decidió asegurarla con una sólida guarnición. A cambio pidió a su vez un complemento de tropas procedentes de África, lanzadores de venablos sobre todo, con armamento ligero, con el fin de que los africanos en Hispania y los hispanos en África, que iban a ser mejores soldados tanto unos como otros lejos de su patria, hicieran su servicio de armas como obligados con rehenes mutuos... Al mismo tiempo, después de enviar reclutadores a las ciudades, ordena que los cuatro mil jóvenes escogidos reclutados sean conducidos a Cartago como guarnición a la vez que como rehenes, (Livio XXI 21, 9-13).

19 Seguramente, los romanos continuaron las relaciones diplomáticas que habían comenzado con los pueblos de ambos lados de los Pirineos, en Hispania y la Galia, tras la toma de Sagunto y la declaración de guerra que después recibieron los embajadores romanos en Cartago (Túnez), para evitar éstos que los cartagineses tuvieran su apoyo y así poder impedir que se lo dieran a Aníbal en la primavera de 218, cuando emprendió su marcha hacia Roma desde Cartagena. Embajada diplomática que, según Livio, inicialmente recibió buena acogida y despertaron en muchos pueblos del otro lado del Ebro las ganas de un cambio de suerte, porque estaban hartos del dominio cartaginés, (Livio XXI 19,7), si bien también añadió que poco después otros hispanos le reprocharon a la embajada romana el que no hubieran apoyado a sus aliados de Sagunto y que los galos no quisieron impedir el paso del ejército cartaginés pues eso conllevaría que la potencia militar de éste recaería sobre ellos en vez de hacerlo sobre Roma. Añadiendo Livio que de esta forma, después de recorrer los pueblos de Hispania y de la Galia, retornan a Roma los embajadores no mucho después haber salido los cónsules hacia sus provincias [de Hispania y África, con sus respectivas legiones romanas]. Encontraron a toda la población tensa a la expectativa de la guerra, al haberse confirmado la noticia de que los cartagineses habían cruzado ya el Ebro, (Livio XXI 19, 9). Pérez también 
tancia de que, tras la exitosa campaña naval por la costa levantina y la de la isla de lbiza, la flota de Gneo Escipión regresó a la parte este de la provincia, donde se encontraron embajadores de todos los pueblos que habitan a este lado del Ebro y de muchos de los confines más remotos de Hispania; pero los pueblos que realmente se sometieron al dominio del imperio romano con entrega de rehenes fueron más de ciento veinte, (Livio XXII 20, 10-11). Livio añadió que entre éstos estuvieron los celtíberos, que habían enviado como embajadores a los principales de su país y habían entregado rehenes a los romanos, instigados por un mensajero enviado por Escipión empuñan las armas e invaden con un fuerte ejército la zona de dominio cartaginés. Toman tres plazas al asalto, a continuación libran con éxito dos combates contra el propio Asdrúbal [en territorio bajo el dominio cartaginés, al norte del Ebro, quizá en territorio de los ilergavones o ak Oeste de éste ${ }^{20} \mathrm{~J}$, dando muerte a quince mil enemigos, y capturan a cuatro mil, junto con un gran número de enseñas militares, (Livio XXII $21,7)$. Acontecimiento que mantuvo ocupadas a las tropas de Aníbal y que permitió que los hermanos Escipión pudieran cruzar el Ebro para encaminarse hacia Sagunto, al final del verano de 217. Aunque los planes de los romanos se vieron inesperada y favorablemente alterados al serles entregados todos los rehenes hispanos que los cartagineses mantenían en Sagunto ya que éstos fueron liberados por medio de una estratagema que puso en marcha un hispano renegado que, entonces, se pasó al bando de los romanos y que estuvo a punto de provocar un levantamiento de los indígenas a favor de éstos, si no hubiera sido porque la llegada del invierno obligó a los ejércitos cartagineses y romanos a retirarse bajo techo en sus respectivos cuarteles hibernales ${ }^{21}$.

propuso que las relaciones diplomáticas que condujeron al sometimiento de los celtíberos a los romanos habría comenzado en cuanto éstos desembarcaron en la península lbérica, en 218, destacando la compleja organización de los celtíberos ya que contaron con legados diplomáticos para negociar con los romanos. Pérez 1991, pp. 210-211 y 226-227.

20 Pérez, entre otros, como por ejemplo Salinas, consideró que el ataque celtíbero que, en 217 a. C. y sirviendo a los romanos, realizaron contra las tropas cartaginesas de Asdrúbal se produjo hacia el interior, en la comarca del Bajo Aragón, al este del río Matarraña, afluente del Ebro por su margen derecha, y que, quizá este territorio confinaba con el extremo oriental de Celtiberia. Lo que explicaría que los romanos pudieran atravesar por el oeste del territorio de los ilergavones hacia el Sur, mientras los cartagineses estaban ocupados luchando contra los celtíberos. Sin embargo, Livio recogió que el levantamiento de Mandonio e Indíbil, el que anteriormente había sido reyezuelo de los ilergetes, en el territorio de éstos, a finales del verano de 217, hizo que Escipión, que se encontraba al sur de la península Ibérica, tuviera que enviar allí a unos tribunos militares con tropas ligeras para sofocar esta escaramuza, lo que provocó que Asdrúbal, que se retiraba hacia el Océano [hacia Lusitania], retrocediera hacia este lado de acá del Ebro para proteger a sus aliados. El campamento cartaginés estaba en territorio ilergavonense y el romano junto a Nueva Clase cuando una noticia inesperada llevó la guerra en otra dirección (Livio XXII 21,5-7). De lo que se deduce que el fuerte ejército celtíbero penetró en el territorio que los cartagineses dominaban en la margen izquierda del Ebro, desde la zona más oriental de ésta y la atravesaron mientras conquistaban varias ciudades hasta que llegaron a enfrentarse con el propio Asdrúbal, seguramente en el territorio que los ilergavones tenían al norte del Ebro. Lo que explica por qué entonces dijo Livio que los dos hermanos Escipión cruzaron al sur del Ebro en dirección a Sagunto ya que mientras los cartagineses están absorbidos por la guerra celtibérica, ellos cruzan el Ebro sin vacilar, y no encontrando ningún enemigo siguen su marcha en dirección a Sagunto, porque se hablaba de que se encontraban allí los rehenes de toda Hispania entregados por Aníbal, custodiados en la ciudadela por una guarnición no muy importante, (Livio XXII, 4). Salinas 1986, pp. 134-135 y Pérez 1991, pp. 209-212 y 219-220, y 2000, p. 49.

21 Livio XXII, 22, 4. 
Con todas estas noticias, Livio mostró el uso habitual que las potencias militares de Roma y Cartago hacían de la toma de rehenes como medio diplomático para someter a los pueblos hispanos aliados a su voluntad y como alternativa a la posterior contratación de sus guerreros como mercenarios. Además, la práctica de la toma de rehenes también tuvo utilidad cuando se convirtió en la liberación de los rehenes tomados por el enemigo. Al menos para los romanos ya que éstos tuvieron la habilidad de usar a su favor la liberación de rehenes hispanos que los cartagineses habían mantenido en Cartagena, cuando conquistaron esta ciudad en 210. De mismo modo que en 179 la liberación de los rehenes que los celtíberos tenían en Alce supuso una baza importante para las negociaciones de los romanos con los que hasta entonces eran aliados de aquellos, Livio XL 49, 4-5. Como lo acredita la descripción que hizo Livio de la delicada negociación que entonces llevó a cabo Escipión, renunciando el rescate de una de las cautivas para ganarse la amistad y fidelidad del joven príncipe celtíbero con el que ésta estaba prometida ${ }^{22}$.

\section{MERCENARIOS DE LOS CARTAGINESES Y, DESPUÉS, DE LOS ROMANOS}

Una vez que los celtiberos se sometieron a los romanos, los cartagineses no tuvieron más remedio que emplear otra táctica para poder seguir contando entre sus filas con tan excelentes tropas auxiliares. Especialmente, después de que el propio Asdrúbal Barca sufriera las consecuencias de su derrota ante los celtíberos, en 217, cuando éstos lucharon contra los cartagineses para cumplir los pactos recién acordados con los romanos. Este momento debió representar un punto de inflexión en la política que los cartagineses habían mantenido hasta entonces con los celtíberos pues, una vez que éstos se habían sometido a los romanos, fue la principal forma con la que pudieron seguir contando con sus servicios.

Por su parte, los romanos debieron negociar con sus nuevos aliados de Celtiberia el que éstos rompieran sus relaciones con los cartagineses pero no debieron conseguirlo ya que el cese de esta actividad bélica, con la que los celtíberos no afrontaban ningún riesgo para su territorio y propiedades, habría supuesto un importante lucro cesante que no habrían podido asumir. De ahí que los romanos cambiaran su tradicional forma de proceder y, por primera vez en su Historia, en el invierno de 213 a 212, se decidieran a contratar los servicios de mercenarios para que formaran junto a sus legiones, a la vez que con ello también evitaban que lo hicieran en las de sus enemigos cartagineses. Sólo tuvieron que pagarles a los celtíberos lo mismo que hasta entonces éstos habían venido recibiendo de los cartagineses por sus servicios como mercenarios $y$, además, les pagaron por otro tipo

22 Al margen de que puedan ser retóricos o no los detalles relacionados con que éste no aceptara el cobro del rescate que le ofrecían los familiares de ella y que así se supo congraciar así la amistad y fidelidad del joven príncipe celtíbero que, en agradecimiento, acabó aportándole 1.400 jinetes celtíberos escogidos, seguramente, entre su clientela, como expuso Quesada, o bien en el territorio de la gentilidad o tribu que estaba bajo su responsabilidad. Livio XXVI 50, 2 y Quesada 2003, pp. 125 y 144. 
de servicio tan importante o más que el de que los celtíberos se incorporaran a los ejércitos romanos como tropas auxiliares y que ya no lo fueran a hacer en los de los cartagineses, pues los romanos también contrataron entonces a más de 300 jóvenes hispanos de la alta nobleza para que tratasen de atraerse a los paisanos suyos que servían como auxiliares en el ejército de Aníbal, (Livio, XXIV, 49, 7-8) 23 .

Sin embargo, la experiencia romana de utilizar mercenarios como tropas auxiliares pronto les demostró las limitaciones de esta táctica, como bien comentó Livio con la intención de que, además, sus palabras le sirvieran de lección a los romanos y que de ellas aprendieran que sus ejércitos no debían estar nunca en minoría frente al número de sus tropas auxiliares. Ya que ésta fue la causa de la desgracia de los hermanos Escipión en Hispania, en 212, cuando los 20.000 celtíberos que éstos habían contratado para luchar contra Asdrúbal Barca fueron convencidos por éste, tras pagar secretamente a sus jefes y a las tropas celtíberas que estaban al servicio de los romanos, para que abandonasen a éstos ${ }^{24}$ y no luchasen contra los cartagineses ${ }^{25}$.

Es posible que, tras la muerte de los hermanos Escipión, los celtíberos se contasen entre los pueblos hispanos que se habían rebelado y que así seguían cuando Publio Cornelio Escipión (hijo de su homónimo padre) desembarcó en Ampurias (Gerona), a finales del verano de 211 a. C. Aunque no hay constancia explícita de que ello fuera así ni tampoco de que se encontraran entre los pueblos que se habían mantenido fieles a los romanos y que entonces enviaron delegaciones de todas partes de Hispania para entrevistarse con el nuevo general Escipión, en Tarragona ${ }^{26}$. Sin embargo, dado que en la toma de Cartagena, de 210, Escipión liberó al gran número de rehenes hispanos que allí habían retenido los cartagineses ${ }^{27}$ y que, entre ellos, se encontraba personas tan destacadas como la esposa del Mandonio, hermano de Indíbil, reyezuelo de los ilergetes, (Livio XXVI 49, 11) o la citada prometida del joven príncipe celtíbero Alucio ${ }^{28}$, es muy probable que los celtíberos hubieran vuelto a someterse a los cartagineses desde la muerte de los hermanos Escipión

23 En las Períocas del libro XXIV se citan dos referencias a los celtíberos, que deben corresponder a este momento, cuyos textos son: También fueron acogidos en amistad los celtíberos (24, 8). Y como se les habían pedido tropas auxiliares, por primera vez un campamento romano albergó entonces a soldados mercenarios $(24,9)$. Información que también recogió Orosio, diciendo que los Escipiones atrajeron a su servicio, apartándolos de su alianza con los enemigos y comprándolos con dinero, a soldados celtíberos, los cuales fueron el primer grupo extranjero que los romanos empezaron a tener a su servicio, (Orosio 4, 16, 14).

24 No obstante, conviene señalar que a Livio no le pareció mal que los celtíberos abandonaran a Escipión ya que se debía a una práctica que, como hemos visto, también emplearon los romanos cuando enviaran a más de 300 jóvenes nobles hispanos a Italia para intentar que sus paisanos abandonaran el ejército de Aníbal, en 213, y que lo que destacó el analista latino acerca de estos acontecimientos fue el hecho de que el ejército de Gneo Cornelio Escipión, con sólo un tercio del ejército romano, se encontrara en minoría y que dependiera completamente su suerte de lo que decidieran hacer los mercenarios celtíberos, convirtiendo este relato en una moraleja.

${ }^{25}$ Livio, XXV 32, 3 y 8-9, XXV 33, 1, 3 y 7, XXVI 41, 21 y XXVIII 42, 8.

26 Livio XXVI 18, 1-2 y 19, 12-14.

27 Después [de la conquista de Cartagena] hizo venir [Escipión] a los rehenes de las poblaciones de Hispania, cuyo número no me atrevo a consignar, pues en unos encuentro que eran trescientos, $y$ en otros, que tres mil setecientos veinticuatro, (Livio XXVI 49,1).

28 Livio XXVI 50, 2. 
hasta entonces. Lo que concuerda con que, en 209, tengamos noticias de que los cartagineses volvieron a reclutar mercenarios celtíberos para el ejército que Asdrúbal ${ }^{29}$ llevó entonces a Italia ${ }^{30}$, si bien Livio sólo recogió que Asdrúbal debía irse a Italia, epicentro de la guerra donde se decidía todo, llevándose al mismo tiempo a todos los hispanos lejos de Hispania y del nombre de Escipión, (Livio XXVII 20, 6).

Posteriormente, en 207, cuando parecía que la guerra había basculado hacia Italia con el paso de Asdrúbal, en la misma medida en que había perdido peso en Hispania, de pronto se rompieron otra vez aquí las hostilidades igual que antes. En aquella época las Hispanias estaban ocupadas por los romanos y los cartagineses de la forma siguiente: Asdrúbal, el hijo de Gisgón, se había retirado hasta los confines del Océano, a Cádiz; la costa del Mediterráneo y casi toda la zona este de Hispania estaba bajo el dominio de Escipión y de Roma. Un nuevo general, Hannón, que había cruzado desde África con un nuevo ejército para reemplazar a Asdrúbal Barca y se había unido a Magón, en poco tiempo había armado un gran número de hombres en Celtiberia, que está situada entre los dos mares, (Livio XXVIII 1, 1-5). Concretamente, dicho general cartaginés había armado un ejército de más de 9.000 jóvenes e inexpertos celtíberos, entre los que se encontraban 4.000 con escudo largo, 200 jinetes y el resto era infantería ligera. Pero no pudo hacer uso de ellos ya que sus tropas y las de los reclutas celtíberos fueron derrotadas en sus correspondientes campamentos por los romanos que penetraron por primera vez en Celtiberia, bajo la dirección de Marco Julio Silano y guiados por desertores celtíberos, según la detallada descripción que Livio hizo de esta campaña ${ }^{31}$.

La penetración de tropas romanas en Celtiberia supuso un nuevo punto de inflexión en las relaciones existentes entre éstas y los celtíberos pues, si existía un pacto de no agresión entre ellos, los romanos lo habían incumplido ${ }^{32}$.

29 Según Apiano, en 209, y los generales de los cartagineses, los dos que quedaban, que también se llamaban Asdrúbal, uno, el hijo de Amilcar, trataba de reclutar mercenarios entre los celtíberos en las regiones más alejadas, mientras el otro, el hijo de Giscón, enviaba mensajeros a las ciudades que todavía se mantenían leales..., (Apiano VI 24) y Asdrúbal, el hijo de Amilcar, que todavía se hallaba reuniendo un ejército en los aledaños del océano septentrional, su hermano Aníbal le llamaba para que se lanzase a toda prisa sobre Italia. Y éste, para pasar inadvertido a Escipión franqueó los Pirineos hacia los galos siguiendo a lo largo de la costa norte con todos los celtíberos que había conseguido reclutar. Y Asdrúbal, de esta forma, se apresuró hacia Italia sin que se apercibieran los propios Itálicos, (Apiano VI 28), a donde llegó en la primavera de 208 a. C.

30 Livio XXVII 19, 1.

31 Livio XXVIII 1, 4 y 6-7, y XXVIII 2, 4, 7, 10 y 12-13. A pesar de ello, se ha generalizado la idea de que ni las iniciales acciones de los cartagineses ni su posterior enfrentamiento [de los celtíberos] con los romanos, centrado en el último cuarto del siglo III con motivo de la segunda guerra púnica, tiene como lugar este territorio [Celtiberia], que de esta manera queda ignoto dentro de una amplia tenaza que lo rodea por el sur y el noreste, espacios donde se sucederán los ataques cartagineses y romanos, (Burillo 2008, p. 268).

${ }^{32}$ La oportuna victoria de Silano en Celtiberia no sofocó la conflagración bélica que se había desencadenado, es cierto, pero sí ahogó el germen de la guerra que habría sobrevenido si los cartagineses hubieran tenido la posibilidad de levantar en armas a otros pueblos después de sublevar a los celtíberos. Por eso Escipión felicitó vivamente a Silano y, abrigando la esperanza de poner fin a la guerra si él mismo no lo frustraba por andar remiso, marchó contra Asdrúbal, al último confín de Hispania, que era lo que quedaba de la guerra, (Livio XXVIII 3, 13-14). 
Los celtíberos debieron considerar esta provocación como un motivo suficiente para sublevarse, explicándose así por qué pocos meses después, sus jóvenes guerreros, como veremos más adelante, fueron sensibles a la llamada que hicieron Indíbil y Mandonio, acompañándoles en las dos campañas que llevaron a cabo en Sedetania, en 206. No obstante, poco antes de éstas, los cartagineses lograron su objetivo de reclutar mercenarios celtíberos entre los hispanos, aunque para conocer los detalles tenemos que complementar los textos de Livio con la narración de Apiano ya que, de acuerdo con la costumbre de aquél, al no ser sólo celtíberos los hispanos reclutados entonces como mercenarios, no los citó explícitamente.

Por Livio sabemos que, estando Escipión en Cartagena, llegaron de Cádiz unos desertores ofreciéndose a entregar la ciudad y la guarnición junto con la flota. Magón se había detenido allí [Cádiz ${ }^{33}$ ] en su huída y después de recoger las naves del Océano había reunido bastantes tropas auxiliares procedentes tanto de la costa de África, al otro lado del estrecho, como, gracias a la labor de su prefecto Hannón, de los lugares de Hispania más próximos. Después de un compromiso mutuo [de Escipión] con los desertores fueron enviados allí Marcio, con cohortes ligeras, $y$ Lelio, con siete trirremes y una quinquerreme, para dirigir las operaciones en un plan combinado por tierra y mar, (Livio XXVIII 23, 6-8). Por lo que entre estas tropa auxiliares de Magón no había celtíberos. Sin embargo, poco después y siguiendo con la narración de los acontecimientos de 206, Livio añadió que por las mismas fechas, en las proximidades del río Betis, Hannón, prefecto de Magón, enviado desde Cádiz con una pequeña partida de africanos, atrajo a los hispanos con promesas de dinero y armó cerca de cuatro mil jóvenes. Después, perdido su campamento a manos de Lucio Marcio, perdida la mayor parte de sus hombres durante el ataque de la toma del campamento y algunos también durante la huída al perseguirlos la caballería cuando se dispersaron, él se escapó con unos pocos, (Livio XXVIII 30, 1-2). Teniendo constancia por los detalles aportados por Apiano de que entre los mercenarios contratados entonces por Hannón sí que había algunos celtíberos. Aunque parece que éstos estaban ofreciendo sus servicios a los cartagineses al margen de las decisiones de sus ciudades de origen, aliadas o mejor dicho sometidas entonces de los romanos, y que además se encontraban lejos de este territorio cuando fueron reclutados y derrotados por éstos pues en lugar de volver a sus ciudades no les quedó otro remedio que regresar con Magón a Cá$\mathrm{diz}^{34}$. Todo parece indicar que la incursión romana en Celtiberia predispuso a los

${ }^{33}$ La presencia cartaginesa en Hispania se había reducido ya únicamente a Cádiz. Livio XXVIII 31, $1-4$.

34 Apiano recogió que en ese mismo tiempo [206] todavía servían como mercenarios bajo el mando de Magón algunos de los celtíberos y de los iberos, cuyas ciudades se habían pasado del lado de los romanos. Y Marcio en un ataque contra ellos aniquiló a mil quinientos, mientras que los restantes lo evitaron huyendo hacia las ciudades. $Y$ a otros setecientos jinetes y seis mil infantes, bajo el mando de Hannón los acorraló en una colina en la que al carecer de todo se vieron obligados a enviar embajadores a Marcio en busca de una tregua. Pero éste les ordenó que sólo cuando le hubieran hecho entrega de Hannón y los desertores, entonces le enviaran embajadores. Y éstos, en efecto, capturaron a Hannón, que era su general, todos al tiempo, cuando todavía estaba escuchando las propuestas, y le hicieron también entrega de los desertores, y Marcio les exigió también los prisioneros. Y después de tomar esto, les ordenó que llevaran una cantidad establecida de dinero hacia un lugar de la llanura, pues los lugares muy elevados no se ajustaban a quienes están en actitud suplicante. Y cuando descendieron 
celtíberos a aliarse con todos aquellos que estaban en contra de los romanos, sirviendo como mercenarios de los cartagineses y después aliándose con Indíbil y Mandonio, hasta que unos y otros fueron derrotados en el mismo 206, completándose así el dominio romano sobre Hispania.

Finalmente, la última noticia de celtíberos al servicio de los cartagineses data de 203, cuando 4.000 celtíberos fueron reclutados como mercenarios en Hispania para desplazarse al norte de África en ayuda de Cartago ${ }^{35}$ y acabaron sucumbiendo en la derrota que Escipión infringió entonces al ejército de Asdrúbal, hijo de Gisgón ${ }^{36}$. Destacando en esta narración los detalles que aportó Livio acerca de lo conscientes que eran los celtíberos de que su proceder sería considerado como una traición a la magnanimidad con la que veremos que Escipión les había perdonado a los ilergetes y a los que se sublevaron con ellos ${ }^{37}$. Especialmente cuando, desde 206, Celtiberia había vuelto a someterse a los romanos y siendo ésta, la de 203 , la última noticia acerca de mercenarios celtíberos en la segunda Guerra Púnica.

hacia la llanura les dijo: «Habéis llevado a cabo acciones dignas de la muerte, quienes teniendo vuestras patrias sometidas a nosotros elegisteis hacer campaña en su contra junto con los enemigos, en cambio os concedo que marchéis indemnes si deponéis las armas». Tras la irritación inmediata de todos y el clamor general de que no depondrían las armas, tuvo lugar un duro combate. Y la mitad de los celtíberos resultó aniquilada a pesar de haber ofrecido una fuerte resistencia, en tanto que la otra mitad acudió a refugiarse junto a Magón. Éste hacía poco que había acudido por mar al campamento de Hannón con sesenta naves de guerra, y tras enterarse del desastre de Hannón, levó anclas hacia Gades y en medio de penalidades por causa del hambre esperaba el curso de los acontecimientos, (Apiano VI 31). Aunque la cifra de hispanos reclutados por Hannon no coincide con la que registró Livio, parece tratarse del mismo suceso. Si bien, Apiano aportó más detalles acerca del asalto romano al campamento cartaginés y acerca de la captura de Hannon, de los que Livio no trató.

35 Livio XXX 7, 10 y 8,6 y 8-9.

36 Pelegrín (2004, p. 174-175 y 177-179) recogió la noticia de que ese mismo año 203 en el que se sitúa el encuentro de los Grandes Llanos todavía actuaban reclutadores púnicos en Hispania, pues en algún momento después del verano y de la partida de Aníbal desde Italia hacia África, citando que, a Roma, por aquellos mismos días llegaron unos legados saguntinos conduciendo a unos cartagineses que habían sido apresados con el dinero que habían cruzado a Hispania para reclutar tropas auxiliares. Depositaron en el vestíbulo de la curia doscientas cincuenta libras de oro y ochocientas de plata. Se recibió y encarceló a los hombres, pero el dinero fue devuelto a los legados dándoles las gracias; además, se les dieron regalos y naves para su regreso a Hispania, (Livio XXX 21, 3-5). Además, Pelegrín citó la ubicación que había dado Walbank (1957, p. 432) del campo de la batalla de los Grandes Llanos en la llanura tunecina de Souk el Kremis a orillas del río Medjerda, y consideró que los reclutadores cartagineses habían sido apresados en las proximidades de Sagunto, relacionando así a los mercenarios celtíberos que se trasladaron ese año al norte de África con los que en 206 habían participado en la sublevación de Indíbil y Mandonio.

37 Pelegrín (2004, p. 175-180) también relacionó la acusación de deslealtad que Livio achacó a estos celtíberos mercenarios que se desplazaron al norte de África en 203, con la clemencia que Publio Cornelio Escipión mostró hacia los celtíberos en las sublevaciones de 206. Llegando, además, a identificar los celtíberos derrotados en Sedetania con estos mercenarios. Hipótesis en la que Pelegrín acertó si con ello quiso decir que no procedían de la Hispania Ulterior, como también propuso en contra de Capalvo y de otros autores que después siguieron la estela de éste, o en la que erró si quiso identificar a los celtíberos de ambos acontecimientos ya que creemos que no hay suficiente base para ello debido a que la referencia de Livio a los celtíberos no parece ser tan concreta sino algo más general. Aunque quizá no sea tan abstracta como supuso Burillo (2008, p. 35), quién llegó a decir que las menciones sobre alianzas y enfrentamientos de cartagineses y romanos con los celtíberos no debe entenderse en ningún momento como que éstos tengan una identidad que los aglutina a todos políticamente, sino como una alusión imprecisa al todo por la parte. Por todo lo expuesto no puedo estar de acuerdo con la postura de Pelegrín, que defiende las antiguas teorías, por las que existe una Celtiberia 


\section{PARTICIPACIÓN EN LA SUBLEVACIÓN INDÍGENA DE INDÍBIL Y MANDONIO}

En 206, una grave enfermedad que afectó al propio Escipión, cuya gravedad sin embargo exageraron las habladurías, (Livio XXVIII 24, 1), propició dos levantamientos en Hispania Citerior. Una la protagonizaron los ilergetes Indíbil y Mandonio ${ }^{38}$ que, según Livio, se habían hecho ilusiones de dominar Hispania una vez expulsados de ella los cartagineses ${ }^{39}$, [aunque] como nada se había desarrollado de acuerdo con sus expectativas, concitaron a sus coterráneos — que eran los lacetanos—, sublevaron a la juventud de los celtíberos y devastaron con saña el territorio de los suesetanos y sedetanos, aliados del pueblo romano, (Livio XXVIII 24, 3-4). De lo que se deduce que, entonces, los celtíberos tomaron partida por la sublevación de los ilergetes en contra de los romanos y que les acompañaron en su citada campaña de 206, antes de regresar a sus respectivos territorios, una vez acabadas sus correrías ese mismo año ${ }^{40}$. Mientras que acerca del otro levantamiento de ciudadanos romanos, éste, estalló en el campamento cercano al Sucrón ${ }^{41}$; había allí ocho mil hombres, destacados como protección para las gentes que habitan a este lado del Ebro. Ahora bien, su actitud turbulenta no se originó entonces, cuando circularon los inciertos rumores acerca de la vida del general, sino antes ya, con la indisciplina derivada, como suele ocurrir, de una prolongada inactividad, y también porque las condiciones en momentos de paz eran particularmente duras para quienes estaban acostumbrados a vivir más a sus anchas de la rapiña en territorio enemigo, (Livio XXVIII 24, 5-7), añadiendo que el motín se fue paralizando conforme a los legionarios les fueron llegando noticias de que Escipión estaba vivo y bien de salud, así como que había finalizado la sublevación indigena ${ }^{42}$, acabando cuando éste requirió que los amotinados se presentaran ante él, en Cartagena, y, una vez allí, los cabecillas del motín fueron arrestados y ajusticiados, mientras que el resto de los amotinados fueron perdonados por Escipión ${ }^{43}$.

estable en el tiempo de donde proceden los celtíberos que forman parte del mercenariazgo citado en las guerras de Aníbal. En concreto, parte del relato de Polibio sobre la batalla de los Grandes Llanos en el norte de África, al oeste de Útica, en el 203, donde los cuatro mil mercenarios celtíberos de la tropa cartaginesa son considerados por Escipión como traidores. Al rastrear las razones de su anterior vinculación con los romanos, establece una serie de suposiciones no comprobadas, entre las que señala que dichos celtíberos serían los citados por Livio en el 206, junto a ilergetas, suessetanos y edetanos, acertando parcialmente en esto último pero contradiciendo la información que claramente transmitió Livio acerca de Celtiberia y de los celtíberos. Si bien es verdad que la extensión de Celtiberia no debió ser siempre la misma y que más allá de la Celtiberia nuclear, su extensión máxima fluctuó con el tiempo, somos de la opinión de que sí que existió una Celtiberia más o menos estable en el tiempo. Al menos, de acuerdo con el relato de Livio.

38 Moret publicó recientemente un interesante sobre las relaciones y el gobierno de Indíbil y Mandonio. Moret 2002-2003, pp. 26-29. $1-4$.

39 La presencia cartaginesa en Hispania se había reducido ya únicamente a Cádiz. Livio XXVIII 31,

40 Livio XVIII 31, 5.

41 Río Júcar. Blázquez 1894, p. 393.

42 El motín, que ya se estaba debilitando por sí sólo, se apaciguó del todo con la repentina vuelta a la calma de los hispanos. Renunciando, en efecto, a su propósito cuando llegó la noticia de que Escipión estaba vivo, Mandonio e Indíbil habían retornado a su territorio, y los amotinados ya no tenían a nadie, ni compatriota ni extranjero a quien asociar a su destino. Livio XXVIII 25, 11-13.

43 Livio XVIII 25 
Por su parte, de regreso a su territorio, Mandonio e Indíbil se mantuvieron quietos durante un tiempo, a la expectativa, hasta saber en qué paraba la sublevación, confiando en que si se perdonaba el extravío de unos ciudadanos, también a ellos se les podría perdonar. Pero cuando se divulgó la noticia del horrible castigo pensaron que su culpa había sido evaluada en una pena similar; llamaron de nuevo a las armas a sus coterráneos, reunieron las tropas auxiliares con que habían contado anteriormente y pasaron con veinte mil soldados de infantería y dos mil quinientos de caballería a territorio sedetano, donde habían tenido un campamento permanente al principio de la sublevación, (Livio XXVIII 31, 5-7). Tropas auxiliares de los sublevados entre las que debieron volver a estar los celtíberos, a pesar de que Livio no los citara explícitamente en esta ocasión.

Escipión organizó su ejército en Cartagena y en diez jornadas llegó al río Ebro. Luego cruzó el río y, tres días después acampó a la vista del enemigo [posiblemente, en el territorio de los lacetanos], (Livio XXVIII 33, 1-2). Alcanzando la victoria sobre éstos en el mismo día en que se enfrentó a ellos, aunque entre los hispanos que huyeron también se encontraban los propios régulos, que se habían escabullido en plena confusión antes de que quedase rodeado todo el ejército, (Livio XXVIII 33, 17). A continuación, Indíbil, renunciando a los proyectos bélicos y pensando que lo más seguro en su difícil situación era la probada lealtad y clemencia de Escipión, le envió a su hermano Mandonio. Éste, postrado de rodillas, echó las culpas al fatal delirio de unos tiempos en que, como contagiados por una epidemia, se habían vuelto locos no sólo los ilergetes y los lacetanos sino incluso el campamento romano; (Livio XXVIII 34, 3-4), consiguiendo el magnánimo perdón de Publio Cornelio Escipión para todos los participantes en la sublevación, a cambio de su renovada fidelidad y del pago de una multa ${ }^{44}$. Perdón que se hizo extensivo a los celtíberos, que así volvieron a estar sometidos a los romanos sin que se les aplicara ningún castigo por la deslealtad demostrada hacia éstos, en concordancia con la referencia que Livio hizo acerca de que, en 203, los celtíberos no tenían esperanzas de perdón por parte de Escipión, contra el que habían ido a África a combatir con armas mercenarias a pesar de lo bien que se había portado con ellos y con su pueblo, (Livio XXX 8, 6 y 8).

No hay duda de que ambos levantamientos de 206 estuvieron relacionados ${ }^{45}$ y parece que contaron con el apoyo de los cartagineses ${ }^{46}$, tal como aclaró Apiano ${ }^{47}$, aunque no tuvieron el éxito esperado por sus promotores ni por quienes les apoyaron.

44 Apiano también hizo una mención resumida de este episodio de rebelión hispana. Apiano VI 37.

45 En el discurso que Escipión dirigió a los legionarios rebeldes, antes de ajusticiarlos, dijo que vosotros compartisteis los planes de Mandonio e Indíbil y estuvisteis además a punto de compartir las armas, Livio XXVIII 28, 5.

46 Al partir ellos [Lelio y Marcio de regreso a Cartagena], Magón, que sufría la presión de la amenaza doble, por tierra y por mar, no sólo respiró aliviado sino que incluso concibió esperanzas de reconquistar Hispania al enterarse de la sublevación de los ilergetes, y envió mensajeros al senado de Cartago con instrucciones de exagerar tanto el motín del campamento romano como la rebelión de los aliados, para animar al senado a que enviase refuerzos con los que poder recuperar el dominio de Hispania heredado de sus padres, Livio XXVIII 31, 3-4.

47 Muchos soldados de las guarniciones acudieron a unirse a ellos [al campamento sublevado] e incluso algunos enviados de Magón trataban de persuadirles por medio de dinero para que se pasasen a su bando. Ellos aceptaron el dinero y tras elegir generales y centuriones entre sus propias filas y haberse organizado también en todo lo demás, se colocaron bajo su propia disciplina militar y se dieron mutuos juramentos unos a otros, Apiano VI 34. 


\section{MOVILIDAD DE LOS CELTÍBEROS Y UBICACIÓN DE CELTIBERIA}

Hemos visto que tan sólo una de las acciones bélicas en las que consta la participación de los celtíberos tuvo lugar en Celtiberia ${ }^{48}$ y que el resto sitúa la presencia de celtíberos fuera de su territorio, concretamente, en dos ocasiones en Sedetania ${ }^{49}$, dos en sendos lugares cerca de la costa mediterránea ${ }^{50}$ una en las proximidades del valle del Guadalquivir ${ }^{51} \mathrm{e}$, incluso, otras dos fuera de la península Ibérica: una en la campaña de Aníbal en Italia ${ }^{52}$ y otra también apoyando a los cartagineses en África ${ }^{53}$. Sin embargo, eso no quita para que, como hemos visto, los contingentes de celtíberos desplazados al servicio de romanos, bien como mercenarios o debido a las obligaciones resultantes de los rehenes bajo custodia romana, fuesen de 20.000 en una ocasión ${ }^{54}$ y de una cifra no mucho menor en la otra, cuando se enfrentaron con las tropas de Asdrúbal al norte del Ebro, seguramente en territorio de los ilergavones, si tenemos en cuenta el número de bajas que ocasionaron a éstas ${ }^{55}$.

Más baja fue la participación de mercenarios al servicio cartaginés, pues el ejército que formó Hannón sólo llegó a contar con 9.000 reclutas celtíberos, antes de ser derrotados cuando quizá no habían acabado de hacer la leva prevista en Celtiberia ${ }^{56}$, y fueron sólo setecientos jinetes y seis mil infantes, según Apiano, los celtíberos mercenarios al servicio de Magón que en parte consiguieron huir con éste ${ }^{57}$, así como otros 4.000 los celtíberos que ayudaron a Asdrúbal y Sífax en la costa mediterránea de África ${ }^{58}$. Si bien es verdad que ambas cifras debieron ser superiores, seguramente, a las del número de jinetes celtíberos que acompañaron

48 Livio XXVIII 1, 4 y 6-7 y XXVIII 2, 4, 7, 10 y 12-13. Dato que, como recogió Pelegrín, ya confundió a Schulten, que llevó todas las referencias tempranas hechas a los celtíberos al Sistema Ibérico, y, recientemente a Gómez Fraile, que consideró que la denominación de celtíberos recayó sucesivamente en pueblos célticos del interior de la península lbérica, en función de su intervención como enemigos de Roma en la segunda Guerra Púnica, por no tener en cuenta la evidencia de que, por definición, los mercenarios no sólo actúan a sueldo al servicio de terceros sino que, además, lo hacen en un territorio distinto de su lugar de origen. Del mismo modo que, previamente, Blázquez se equivocó al considerar todas las referencias a los celtíberos fuera de Celtiberia como pruebas de su expansión hacia el este y el sur de la península Ibérica. Blázquez, pp. 417-421 y Pelegrín 2005, pp. 130-131.

49 En una ocasión son citados los celtíberos explícitamente entre los aliados de los ilergetes sublevados y en otra implícitamente. Livio XXVIII 24, 4 y XXVIII 31, 5-7.

50 Una ocasión al Norte del Ebro y otra en el Sur de la península lbérica, en el episodio bélico en el que fallecieron los hermanos Escipión. La deserción de los celtíberos del campamento de Gneo Cornelio Escipión acaeció cerca de la ciudad de Amtorgis, lugar que no debía estar lejos de donde falleció este Escipión y que, según Plinio fue en la ciudad de llorci, ubicada en la cabecera del río Guadalquivir. Livio XXII 21,7 y XXII 22,4, así como XXIV 49, 7 y 8; 32, 3, 8 y 9, y XXV 33, 1, 3 y 7, respectivamente, y sobre la ubicación geográfica de éstas ciudades véase, Pérez 1991, pp. 207-216 y 226-228, y Bellón, Wiña, Gómez, Lozano, Gutiérrez, Ruiz, Sánchez, Rueda, Molinos y García 2004, p. 20.

51 Livio XXVIII 30, 1-2.

52 Livio XXI 57, 5, XXII 21, 7 y XXIV 49, 8.

53 Livio XXX 7, 10 y XXX 8, 6 y 8.

54 Livio XXV 32, 3 y 8-9.

55 Livio XXII 21, 7 y XXII 22, 4.

56 Livio XXVIII 1, 4 y 6-7 y XXVIII 2, 4, 7, 10 y 12-13.

57 Apiano VI 31 o 4000 jóvenes hispanos, según Livio XXVIII 30, 1-2.

58 Livio XXX 7, 10 y XXX 8, 6 y 8. 
a Aníbal en su campaña transalpina contra Roma ${ }^{59}$. Aunque no por ello dejan de ser significativas para evaluar la capacidad de las tropas de jóvenes celtíberos para desplazarse allí donde sus servicios fueran requeridos, ni tampoco la capacidad de convocatoria que tenían sus líderes o de la fidelidad de su clientela pues también hemos visto que uno de ellos fue capaz de poner al servicio de los romanos a 1.400 jinetes escogidos ${ }^{60}$. Lo que también pone de manifiesto el número de líderes y ciudades celtíberas que debieron congregarse para formar ejércitos de una o varias decenas de miles de jóvenes guerreros, desplazándose por territorios bien alejados de Celtiberia.

Con respecto a la ubicación de este territorio, Livio sólo aportó dos datos mientras relataba los acontecimientos acaecidos en la segunda Guerra Púnica. Con el primero de ellos lo situaba directa pero vagamente en el interior de la península lbérica, con la intención de que sus comentarios le sirvieran de lección a los romanos y que aprendieran que no debían estar nunca en minoría frente al número de sus tropas auxiliares, al decir que se encontraba entre los dos mares: el Mediterráneo y el Océano Atlántico ${ }^{61}$. Mientras que, en la segunda ocasión, al describir el final de la citada campaña victoriosa de Marco Silano en Celtiberia ${ }^{62}$, en 207, aportó el dato de que casi toda la caballería y los veteranos que habían seguido a Magón en su huida llegaron a los nueve días al lado de Asdrúbal, a la circunscripción de Cádiz. Los reclutas celtíberos se dispersaron por los bosques vecinos y de allí huyeron a sus distintos lugares de residencia, (Livio XXVIII, 2,12), con lo que, indirectamente, señaló la distancia en la que se encontraba el territorio de los celtíberos. La información aportada por este último dato, cuantificado en $400 \mathrm{~km}$ por Schulten y en sólo $300 \mathrm{~km}$ por Capalvo ${ }^{63}$, se comprende mejor cuando se tiene en cuenta que, poco después, Livio describió el principio de la campaña que emprendió Publio Cornelio Escipión con las tropas mandadas por el mismo Marco Silano contra los lacetanos, con objeto de castigar a los sublevados bajo el mando de Indíbil y Mandonio, aclarando que este ejército romano partió de Cartagena, (Livio XXVIII, 26, 7 y 32, 2), y que emprendida la marcha, en diez jornadas llegó al río Ebro, (Livio XXVIII, 33, 1). Lo que permite hacerse una idea mejor acerca de la distancia que debió existir entre el campamento de Hannon en Celtiberia y la circunscripción de Cádiz (Andalucía), especialmente, si consideramos que, en su huida, los cartagineses pudieron recorrer una distancia mayor incluso que la de un ejército cargado con sus bagajes y marchando ordenada-

\footnotetext{
59 Livio XXI 57, 5.

60 Livio XXVI 50, 2.

61 Livio XXVIII 1, 4
}

62 Se trata de la primera incursión de tropas romanas en Celtiberia, lo que explica el hecho de que Silano fuera guiado por desertores celtíberos, (Livio XXVIII 1, 4 y 6-7).

63 Schulten consideró que puesto que Magón, con la caballería, desde el campo de batalla hasta el país de Gades tarda diez días, puede calcularse en 400 kilómetros la distancia entre Gades y el campo de batalla. Con esto, midiendo por el Betis hacia arriba, se llega aproximadamente al país de las fuentes del Betis, o a la parte meridional de la meseta pero no a Celtiberia propiamente dicha. Dato que corrigió Capalvo al considerarlo incorrecto, ya que Livio dice «Magonem fugientem equitatus omnis et quod ueterum pedium erat secuti, decimo die in Gaditanam prouinciam ad Hasdrubalem peruenerunt». Es decir, que Magón no sólo huyó con caballería, sino también con infantería, lo que obliga a calcular en un máximo de trescientos kilómetros la distancia entre el campo de batalla y la gaditana prouincia donde se encontraba Asdrúbal. Schulten 1935, p. 130 y Capalvo 1999, p. 136. 
mente hacia una batalla. Con lo que también podríamos desechar las hipótesis propuestas por Schulten y Capalvo acerca de su ubicación en la parte meridional de la meseta o en las actuales provincias andaluzas de Málaga y Cádiz, respectivamente. A la vez que se pone de manifiesto que la Celtiberia descrita por Livio no se encontraba situada en una región muy distinta a la considerada por la mayoría de quienes han descrito o estudiado sus límites hasta nuestros días ${ }^{64}$ y que se corresponde con la región que hemos descrito al principio de este trabajo, cuando tratamos acerca de la vinculación del límite septentrional de Celtiberia con el del dominio cartaginés al Sur del Ebro.

\section{EL FINAL DE LA SEGUNDA GUERRA PÚNICA EN HISPANIA}

En la obra de Livio sólo hay tres referencias a los celtíberos entre la salida de los cartagineses de la península lbérica, en 206, y el final de la segunda Guerra Púnica, en 201, que también lo fue de la guerra que los romanos mantuvieron con los hispanos sublevados ya que, en palabras de Livio, relativas a los acontecimientos del año 197, consta que: La guerra recomenzó en Hispania cuatro años después de haber finalizado a la vez que la guerra púnica, (Livio XXXIII 26, 5).

Las dos primeras corresponden a las dos campañas de 206 en las que hemos visto que los celtíberos se unieron a la sublevación hispana liderada por los hermanos Indíbil y Mandonio, cuando a los cartagineses sólo les quedaba ya el reducto de Cádiz. Segundo caso, junto con el de las consecuencias de la muerte de los hermanos Escipión, en el que hay constancia de que los celtíberos se rebelaran contra los romanos desde su temprano sometimiento, en 217. Pues parece que los celtíberos supieron mantener Celtiberia al margen del conflicto púnico-romano y arreglárselas para sacar partido de él sirviendo a ambos bandos como mercenarios. Como hemos visto, la citada sublevación de los celtíberos debió ser consecuencia del ataque que los romanos realizaron en su primera y única incursión en Celtiberia con objeto de desbaratar la leva de mercenarios por parte de los cartagineses, en 207, lo que también hemos visto que debió suponer 0 , al menos, ser considerado por los celtíberos como una ruptura de los acuerdos alcanzados con los romanos.

64 A excepción de la reciente hipótesis de Capalvo acerca de la ubicación de una Celtiberia Ulterior al sur de la península Ibérica, en la Hispania Ulterior, que, sin embargo, como dijo Ciprés, los testimonios de los autores clásicos y el propio relato de Livio nos llevan a dudar de la existencia, en primer lugar, de una Celtiberia percibida como una región dividida en dos partes perfectamente «institucionalizadas" a los ojos de Roma y, en segundo lugar, de la presencia de una Celtiberia en el sur peninsular. A lo que Burillo añadió que se puede concluir que no existen argumentos fundados para defender la existencia de una Celtiberia Ulterior en la Bética. Sin embargo, la teoría clásica de dividir la Celtiberia en dos regiones, Citerior y Ulterior, ha tenido éxito entre los historiadores actuales, dado que refleja grosso modo las diferencias existentes en los territorios celtibéricos situados en la cuenca del Ebro y del Duero. Teoría clásica que sería similar a la que da por supuesta la separación del territorio de los vascones entre el ager y el saltum, sin que tampoco haya ninguna base argumental para ello, tal como lo señalamos al tratar acerca del ager vasconum y el itinerario de Sertorio en el 77-76, también siguiendo el relato de Tito Livio. Capalvo 1996, 107-116 y 134-136, Ciprés 2006, pp. 192-193, Olcoz y Medrano 2006, pp. 61-62 y Burillo 2008, pp. 40-42. 
Mientras que la tercera y última referencia a los celtíberos, también hemos visto que data de 203, situándolos en el Norte de África, como un contingente de mercenarios al servicio de los cartagineses que ya luchaban contra los romanos cerca de Cartago.

\section{ORGANIZACIÓN DE LOS CELTÍBEROS}

Tras haber revisado la información aportada por Livio acerca de la actividad militar en las campañas y expediciones que llevaron a cabo cartagineses, romanos e incluso hispanos sublevados frente a estos últimos, creemos que también vale la pena explorar la información que se puede extraer acerca de su actividad diplomática y de cómo estaban organizados los celtíberos, durante el período correspondiente a la segunda Guerra Púnica. Pues hemos visto que Livio, en todo momento, se refirió a los celtíberos como si se tratara de un único pueblo que habitaba y gobernaba en el territorio concreto de Celtiberia. A pesar de que sabemos que, posteriormente, otros autores clásicos, como por ejemplo Estrabón, aportaron información acerca de la evolución temporal de los límites geográficos de Celtiberia y de la compleja diversidad étnica de los celtíberos, sin salir del ámbito celta pues éste debió ser el origen de los celtíberos ${ }^{65}$.

La desafortunada solución que se viene aceptando para resolver este complejo dilema consiste en considerar las referencias a los celtíberos como una generalización de la denominación correspondiente a pueblos más o menos conocidos por los autores clásicos, incluido Livio, que, sin embargo, les identificaron de una forma concreta y distintiva como celtíberos. Pues hemos visto que, por ejemplo, éste distinguió claramente a los celtíberos de otros pueblos limítrofes a los que citó por sus nombres, como los vacceos, carpetanos e incluso los ólcades ${ }^{66}$, por ejemplo, evitando el uso de potenciales genéricos y que, además de esta distinción, vamos a ver que también aportó alguna información acerca de su organización interna y de sus relaciones como pueblo o, mejor dicho, como estado territorial que estaba bajo el gobierno de la liga o confederación celtíbera ${ }^{67}$, pero que, a pesar de su compleja

65 Estrabón acerca del origen celta de los celtíberos y berones al decir que las regiones septentrionales de los celtíberos están habitadas por los berones, vecinos de los cántabros coniscos, también ellos procedentes de la migración céltica, (Estrabón III 4, 12).

66 Livio XXI 5, 3-17.

67 La hipótesis de considerar que Celtiberia fue estado territorial bajo la gestión de la liga o confederación de los pueblos cuyos miembros eran conocidos como celtíberos va en línea opuesta a la opinión de Burillo, entre otros, pues Burillo expuso que nunca hubo un estado celtíbero, ni siquiera belo o arévaco. Lo que las fuentes escritas muestran y la arqueología ratifica para la etapa histórica es la existencia de un territorio políticamente atomizado en ciudades estado. Esta ausencia de unidad política de lo celtibérico dio lugar a que no se desarrollaran procesos de identidad que pudieran tener reflejo en aspectos específicos de la cultura material o de los patrones de asentamiento, y que pudieran servir para identificar una fase de "lo celtibérico» a partir de la lectura arqueológica. Ni que decir tiene que la cultura material servirá todavía menos para conocer las fases históricas anteriores de estas poblaciones, dado que no se ha demostrado que sean exclusivamente de un grupo políticamente constituido, por lo que su dispersión sólo marca relaciones culturales, sociales o económicas y nunca pueden definir una entidad cultural celtibérica ni mucho menos étnica. Burillo 2008, pp. 153-154. 


\section{composición étnica y gracias a que funcionó como una liga estable ${ }^{68}$ de los pueblos que la formaban ${ }^{69}$, fue capaz de pactar con otros estados coetáneos como el de}

68 La liga de los celtíberos no fue una confederación temporal u ocasional, pues perduró a lo largo del tiempo y Livio, entre otros autores clásicos, hizo mención a la actividad de los celtíberos, como tales, en contextos muy diversos, por lo que su propósito tampoco fue meramente defensivo ni estrictamente ofensivo, como ocurrió en otros casos y entre otros pueblos hispanos. Quesada expuso que no hay forma de saber si las alianzas entre los distintos pueblos hispanos, que se enfrentaron a los cartagineses o a los romanos tuvieron una base temporal y ocasional, aunque con cierta consistencia, o si eran alianzas a largo plazo, así como si tuvieron una función únicamente ofensiva o puramente defensiva. Sin plantearse la posible complejidad étnica de los celtíberos subyacente a la confederación celtíbera que sí hemos visto que planteó Salinas. Quesada 2003, p. 118.

69 Aproximación que no es del todo novedosa ya que Salinas señaló que la conquista de Celtiberia fue el resultado de la colisión de los intereses romanos en mantener el dominio sobre las zonas conquistadas a los cartagineses después de la segunda guerra púnica y la expansión de la liga de las tribus celtibéricas en dirección a Carpetania y el valle del Ebro y también un párrafo similar en el que su final por el de que la expansión de la confederación de las tribus celtibéricas, por otra parte, que llevaba a éstas a desbordar su área de orígen hacia Carpetania, Levante y el valle del Ebro, regiones donde controlaban amplias comarcas e importantes ciudades. Aunque Salinas, como luego Ciprés y otros, consideraron que las confederación de los celtíberos, como otras ligas que se dieron en Hispania y que, como hemos visto, también cita Livio sin ir más lejos, fueron de carácter coyuntural y no estable como proponemos nosotros al referirnos al estado celtíbero que encontraron los romanos tras su desembarco en $218 \mathrm{a}$. C. Volviendo a Salinas, conviene añadir que desarrolló su propuesta de organización gentilicia de los celtíberos partiendo de las gentes o unidades familiares para pasar a las unidades suprafamiliares de los clanes o gentitlidades cuya agrupación superior consideraba como tribu celtibérica, asociando entonces la idea de la existencia de otra unidad de agrupación superior que estaría constituida por la confederación tribal, encontrando vestigios de ésta en las fuentes pertenecientes sobre todo al período 154-133 antes de Cristo, aunque con anterioridad, durante las guerras de Fulvio y Graco sea posible ver también que existía un principio de solidaridad entre las tribus celtibéricas, como se puede deducir de la previsión de Graco de llevar al ejército in ultima Celtiberia si las necesidades de la guerra lo exigían. Además, si la liga estaba ya constituida en 154, es de suponer que requirió un período de tiempo más o menos largo para formarse. Por lo que, aunque también había señalado acertadamente la existencia de reyes o caudillos de la confederación de los celtíberos en 181 a. C. y en 193 a. C. (ésta última creemos que no era tal), Salinas se centró en la liga existente entre los numantinos y los segedenses, agrupando éstos, además, a los belos y los titos, declarando que la confederación acogía, por tanto, a las tribus de los arévacos, bellos y tittos, y, puesto que al año siguiente Marcelo atacó también a Nertobriga de los lusones, a la que los arévacos auxiliaron con un ejército de 5.000 hombres, podemos suponer también que agrupaba a éstos y a los pelendones, que, sin embargo, no aparecen mencionados en las fuentes de esta guerra. La base de la confederación la constituía el vínculo gentilicio de la consanguineidad, como expresamente dice Floro, que debía establecer a la vez el límite de la misma, expresado tal vez por la posesión de un tronco dialectal común, como tal vez se entrevé en la existencia de la lengua denominada «celtibérico" y por la unidad del étnico común de Celtiberi. Dejando claro que interpretó adecuadamente las palabras de Floro (33, 13-14), que hemos propuesto en otro trabajo acerca del final del estado federado de los celtíberos, etc., y añadiendo que los objetivos de la confederación eran al parecer los de la guerra y la defensa, cosa en la que estamos de acuerdo, pero también que no parece que a la llegada de los romanos dicha confederación hubiese adquirido forma estable, como llegó a suceder con las de las tribus del Lacio o del Atica, que dieron lugar a sendos Estados, con ceremonias periódicas y rituales que contribuían a robustecer el vínculo gentilicio de la confederación, sino que parece que la asamblea o consejo de de la misma sólo se reunía con ocasión de las circunstancias, como eran los ataques de los romanos. Lo cual no sólo es erróneo sino que, además, contradice lo que el propio Salinas añadió acerca de que la confederación imponía deberes de defensa mutua a cada una de las tribus y, basándose en los principios gentilicios, es importante destacar que actuaba sobre ellas en tanto cuerpos consanguíneos; se explica así que las ciudades, cuyo desarrollo era posterior al de las gentes y en cierto modo se verificaba al margen de la organización tribal, no siempre se sintiesen obligadas a acatar los acuerdos de la misma. En virtud de dichos deberes vemos que los arévacos dieron acogida a los habitantes de Ségeda. Parece que en la práctica de los mismos se contaba el envío de refuerzos y la imposición de destacamentos y guarniciones en las ciudades. En 181, cuando Q. Fulvio Flaco atacaba Contrebia, acudió un ejército de celtíberos en auxilio de la ciudad. Lo mismo ocurre en 152, en que los arévacos envían un ejército de 5.000 hombres a Nertobriga de los lusones, que Marcelo asediaba, pues 
Roma, sin ir más lejos. Hasta que éste acabó sometiéndolo militarmente y dividiéndolo, en 171 o 170, en cuatro partes que ya nunca más volvieron a actuar como un único estado y así, finalmente, los romanos lograron que los pactos de Graco mantuvieran la paz en Celtiberia hasta $154^{70}$.

Entendiendo por tal liga o confederación celtíbera algo similar a lo expuesto por Quesada cuando se refirió a las ligas o confederaciones entre iberos o entre éstos y otros pueblos hispanos, diciendo que de la lectura de las fuentes se deduce que cada grupo étnico poseía un número variable de lugares fortificados (castella) y oppida. Por tanto, la confederación es una suma de unidades compuesta de un territorio con recintos fortificados más o menos grandes $y$, casi con total seguridad, al menos en Levante y Nordeste, granjas y aldeas ${ }^{71}$. Por lo que la existencia de una liga celtíbera estable no impide la compleja composición étnica de Celtiberia, a la que antes nos referíamos, ni entra en contradicción con lo expuesto por las fuentes ni con la actual interpretación de los restos materiales procedentes de yacimientos arqueológicos ubicados en los territorios que, en algún momento de la Historia, pertenecieron a Celtiberia.

La existencia de una liga celtíbera estable conlleva una forma de gobierno sobre todos los pueblos que la integraban y, quizá, también la presencia de un gobernante, rey o caudillo general. A pesar de que Livio citó al rey de la confederación temporal que hicieron vacceos, vetones y celtíberos para luchar contra los romanos en la meseta Central, en 193, Hilerno, durante el período de la segunda Guerra Púnica no se registra, por parte de Livio ni de ningún otro autor clásico, la presencia de un gobernante de toda la confederación celtíbera. Sin

\footnotetext{
haciendo este símil daba a entender que la confederación celtíbera estaba operativa en 181 a. C. Por otra parte, Salinas consideró que las citas de Livio relativas a la presencia de celtíberos en territorio de los ilergavones, suessetanos y sedetanos, así como la incursión en lliturgis, y otras que hacen referencia al período correspondiente a la conquista romana de Celtiberia, entre Catón y Graco, conducían a la conclusión de que las tribus celtibéricas controlaban los valles del Ebro y del Turia, donde realizaban incursiones en busca de botín o donde tenían ciudades a las que les unía un compromiso de defensa. Añadiendo también que mayor era la presión hacia el mediodía, que puso virtualmente bajo control celtibérico el territorio carpetano, donde, nuevamente, vuelve a citar la existencia de la confederación celtibérica al decir acertadamente que a finales del siglo III y comienzos del siglo II las tribus celtibéricas controlaban un territorio más extenso que el que comprendía estrictamente su región, lo que explica la inclusión en las fuentes literarias en la misma de ciudades que estaban muy alejadas de su territorio. Por lo que Salinas, como tantos otros, confundió así los acontecimientos revisados en este trabajo y en el que hemos hecho referencia a la expansión de los celtíberos a principios del siglo II, por lo que coincidimos con sus propuestas sólo en parte, a pesar de que sus frases iniciales acerca de que la conquista de Celtiberia fue el resultado de la colisión de los intereses romanos en mantener el dominio sobre las zonas conquistadas a los cartagineses después de la segunda guerra púnica y la expansión de la liga de las tribus celtibéricas en dirección a Carpetania y el valle del Ebro y también un párrafo similar en el que su final por el de que la expansión de la confederación de las tribus celtibéricas, por otra parte, que llevaba a éstas a desbordar su área de origen hacia Carpetania, Levante y el valle del Ebro, regiones donde controlaban amplias comarcas e importantes ciudades nos parezcan muy acertadas. Salinas 1983, p. 21, Salinas 1986, pp. 9, 40-43, 81-82 y 134135, Ciprés 2006, pp. 66-67 y 97-100, y Olcoz y Medrano 2011, en prensa.

70 Olcoz y Medrano 2011, en prensa.

71 Si bien Quesada matizó que entre los iberos, no sólo no hay concepto supra étnico, sino que incluso la actuación de las diferentes comunidades políticas viene en buena medida definida por los lazos personales que sus líderes contraen con los grandes generales cartagineses primero, y romanos después. Quesada 2003, pp. 119 y 121.
} 
embargo, creemos que sí debió existir ya que consta la referencia a Olíndico, que dirigió el estado celtíbero en su último intento por independizarse de Roma, hasta ser abatido por los romanos en 171 o 170, antes de que hubiera cuajado la sublevación.

Además de este caudillo general, a sus órdenes estaban los príncipes celtíberos a los que hemos visto que Livio mencionó en tres ocasiones, todas ellas relacionadas con actividades diplomáticas que tenían por objeto la congregación o disgregación de alianzas con otros estados, así como en la última también destaca el hecho de que los jóvenes príncipes guerreros se encontraran liderando a las tropas de mercenarios celtíberos dispuestas para entrar en combate ${ }^{72}$ ya que es impensable que ejércitos tan numerosos como los que Livio relató que movilizaron los celtíberos, actuando como mercenarios, sublevados o aliados de los romanos, carecieran de la organización militar que les permitió ser tan bien valorados por cartagineses y romanos, así como para enfrentarse y vencer a ambos en ocasiones en las que quedaba clara la desventaja que les ocasionaba a los celtíberos el uso de tecnología militar más arcaica. Comenzando por su envío como embajadores a los príncipes de su país, (Livio XXII 21, 7) ${ }^{73}$, para pactar su sumisión a Roma en 217, lo que pone de manifiesto la capacidad de la clase dirigente en el estado celtíbero para pactar con otros estados como el romano y antes, seguramente, con el cartaginés. Siguiendo en 212, cuando Asdrúbal negoció en secreto con los príncipes celtíberos el pago de una suma de dinero para que ellos y sus tropas de mercenarios celtíberos al servicio de Gneo Cornelio Escipión se retiraran del campamento romano y no lucharan contra los cartagineses ${ }^{74}$, y acabando en 210, cuando Livio trató acerca de la liberación de los rehenes hispanos de Cartagena y citó al joven príncipe Alucio, capaz de movilizar a 1.400 jinetes escogidos ${ }^{75}$.

72 Este dato hace que para los celtíberos no se pueda aplicar la visión de Muñiz acerca de las relaciones existentes entre los nobles, sus clientelas y las clases populares no integradas en ellas ya que consideró que el monopolio del poder económico y político por parte del grupo nobiliar margina a cuantos ciudadanos no se implicaban en este entramado social. Aparte de los lazos consanguíneos, la única vía de conexión entre el cuerpo nobiliar y los ciudadanos que se ofrece es la clientela. Este cauce de integración no atenúa los efectos del monopolio sino que tiende a consolidar más al grupo nobiliar y acentuar los desequilibrios. Por ello, la existencia de grupos sociales desamparados y desheredados en una civitas es síntoma de solidez y potencia del elemento aristocrático. Para los individuos no integrados en las clientelas, queda como única salida la actividad militar, ya por cuenta propia como bandolero, ya ajena como mercenario que alquila sus servicios. La política de clientelas se proyecta en todo el espectro social, de forma que cualquier tipo de asamblea popular, en gran manera es un reflejo de las luchas de intereses nobiliares a través de sus clientelas. Muñiz 1994b, p. 98.

73 En esta ocasión, creemos que fue una pena que Villar no tradujera literalmente Celtiberi, qui miserant principes suae regionis legatos dederantque obsides Romanis. Mariner 1968, p. 99.

74 [Asdrúbal] llegó a un acuerdo con los jefes celtíberos a través de conversaciones secretas -la comunicación era fácil al estar lleno de hispanos ambos campamentos- para que a cambio de una fuerte recompensa retiraran de allí sus tropas. No les pareció, por una parte, una acción monstruosa no se trataba, en efecto, de que volviesen sus armas contra los romanos-, y por otra parte se les ofrecía, por no hacer la guerra, una suma suficiente como para hacerla, y además resultaban en general agradables tanto el propio descanso como la vuelta a casa y el placer de ver a los suyos y sus cosas. De modo que no resultó más difícil convencer a la tropa que a sus jefes, (Livio XXV 33, 3-5).

75 Un príncipe celtíbero, un joven llamado Alucio, (Livio XXVI 50, 2). 
Estos príncipes debieron formar parte de la monarquía aristocrático-militar o alta nobleza ${ }^{76}$, entendiendo por príncipe un primus inter pares ${ }^{77}$ o caudillo temporal $^{78}$ más que alguien que desempeñara una función monárquica consolidada e institucionalizada y con posible carácter hereditario ${ }^{79}$, y a la que Livio no parece referirse en ningún caso cuando trata de los celtíberos. Príncipes o caudillos entre los que, a su vez, destacaría uno de ellos como caudillo general de los celtíberos que, de forma jerárquica y a través del resto de los príncipes gobernaría sobre toda la juventud guerrera de los celtíberos. Pues, en el largo período de la segunda Guerra Púnica y en el de las diferentes etapas por las que pasó el sometimiento de los celtíberos a Roma, hay constancia de que éstos contaron con una organización basada en dos clases sociales: los jóvenes guerreros ${ }^{80}$ y el consejo de ancianos o senado de sus ciudades ${ }^{81}$. Si bien el ámbito de actuación de esta última debía restringirse inicialmente al de la gentilidad o, como mucho, al de la tribu o ciudad correspondiente mientras que la de los jóvenes guerreros

76 Muñiz expuso que el nivel de riqueza del noble determina su nivel de potencia en el seno de su comunidad. Esta riqueza, que debe sobrepasar a la del común de sus compatriotas, se traduce en la propiedad de ganados, tierras y bienes muebles, en la proporción que sea resultado del sistema económico vigente. La privilegiada posición económica repercute en el disfrute de la preeminencia política, para lo cual el noble no rehúsa competir con otros líderes aristocráticos influyentes. El control y manipulación general de las instituciones, la identificación de sus propios intereses con los del estado, se convierte en último objetivo al que se orientan y dedican todas las iniciativas. Muñiz 1994b, p. 96.

77 Livio también citó entre los mercenarios contratados por los romanos en 213 a. C. a más de 300 jóvenes hispanos de la alta nobleza para que tratasen de atraerse a los paisanos suyos que servían como auxiliares en el ejército de Aníbal, (Livio, XXIV, 49, 7-8).

78 Seguramente, similar a los caudillos o jefes de los diferentes pueblos que se sublevaron con Indíbil y Mandonio y que, tras la muerte de Indíbil, los romanos demandaron la entrega de los caudillos de la coalición de pueblos sublevados. Mandonio y los demás jefes fueron detenidos allí mismo y entregados al suplicio, (Livio XXIX 3, 4).

79 Por lo que no se correspondería con la interpretación más primitivista que asoció Moret al tipo de monarquía existente entre los íberos, a partir del siglo IV a. C. Moret 2002-2003, pp. 23-24.

80 Pelegrín destacó la escasa atención que había recibido el relato acerca de la participación de los celtíberos en el norte de África, especialmente, por parte de los autores modernos. Destacando que, por ejemplo, Ciprés no hubiera tenido en cuenta esta cita de Livio a la egregia iuuentus de los celtíberos, Livio $\mathrm{XXX} 7,10$, precisamente en aquellos trabajos en los que dicha autora examina el significado de la fórmula iuuentus Celtiberorum en los autores latinos. Ciprés 1990, p. 178 y Pelegrín 2004, p. 174.

81 Salinas dio por hecho la existencia de ambas instituciones en una sociedad organizada a la manera gentilicia: el senado de mayores de la ciudad celtibérica, compuesto por los representantes de cada linaje, que no tenían por qué ser ancianos, y la juventud que componía los ejércitos celtibéricos, a quienes identificó con el sector empobrecido y expropiado por la aristocracia gentilicia, al estilo de la organización que tenían los germanos que describió Tácito, según estudió Thompson. Posteriormente, Muñiz, en su estudio sobre las instituciones políticas celtas e ibéricas, planteó que los asuntos militares y civiles requerían la elección de personas distintas y que para la dirección de la guerra, a propuesta de la asamblea o consejo que detentaba la autoridad civil y por medio del príncipe que representaba a éste, como mero ejecutor de la voluntad de dicha autoridad civil, se reunían en asamblea los jóvenes o ciudadanos en edad de portar armas y escogían por aclamación a sus jefes entre los candidatos considerados más aptos para desempeñar dicho liderazgo militar, limitándose después el poder civil a refrendar dicha elección. Ideas similares que también ha propuesto recientemente Ciprés, ampliando los ya expuestos en trabajos anteriores, pero que, como los trabajos de otros autores, adolece de no considerar la evolución temporal de la organización de los celtíberos y, por tanto, de no contextualizar adecuadamente las posibles correlaciones con otras instituciones similares que se dieron en otras partes de Europa o en la propia Celtiberia pero en otro momento histórico. Thompson 1965, pp. 29-60, Salinas 1986, pp. 42-45, Muñiz 1994b, p. 94 y Ciprés 2006, pp. 97-135. 
tuvo un ámbito estatal, mientras Celtiberia fue un estado ya que, después, su ámbito se redujo al de su correspondiente ciudad-estado o el de las alianzas que hiciera, en cada momento, el estado celtíbero al que pertenecían. De hecho la primera referencia a la clase correspondiente al senado ciudadano, data de la época de la última Guerra Celtibérica y en ella también se cita a la clase de jóvenes guerreros. Es más, en esta ocasión el senado de la ciudad celtíbera de Lutia $^{82}$ se puso a favor de los romanos y traicionó a los jóvenes guerreros que habían decidido apoyar a los asediados numantinos ${ }^{83}$. Por lo que no sabemos si esta clase existió con anterioridad a la desaparición del estado celtíbero y lo que ocurre es que no nos han llegado noticias de ellas debido a que los datos conocidos sólo hacen referencia al estado celtíbero en tiempos de guerra, cuando el potencial senado, si existía ya, debía quedar relegado.

No obstante, la percepción arcaica con respecto al estado evolutivo alcanzado entonces por Roma, que Livio dio de la organización del estado celtíbero, en tiempos de guerra al menos, esto es, de cómo se organizaba su juventud guerrera ${ }^{84}$, está en consonancia con la apreciación acerca del primitivo o sencillo tipo de núcleos de población con los que también se asocia a los celtíberos y entre los que abundaban las pequeñas villas y recintos fortificados frente al es-

82 Schulten propuso ubicar la ciudad de Lutia en Cantalucía (Soria), al oeste de la ciudad Numancia (Garray, Soria) y a una distancia acorde con el relato de Apiano. Aunque últimamente se viene relacionando con Luzaga (Guadalajara), a pesar de que, como señaló Sánchez-Lafuente, esta propuesta tiene en su contra que está a casi el doble de distancia de Numancia pero tiene a su favor el hecho de que parece que allí fue encontrada la inscripción celtibérica conocida como bronce de Luzaga, desde que Fita diera cuenta de su existencia en el siglo XIX, y en el que figura el encabezado de arekoratikubos y, después lutiakei, por lo que podría tratarse de un documento "de los de arekorata", en el que se también se mencionaría a los de lutiaka o lutia. Además, Burillo recogió la identificación de la ceca de lutiakos con esta ciudad de Lutia, distinguiéndola de su homónima ubicada en Luzaga. Aunque le agradecemos que, en comunicación personal nos añadiera que respecto a Luzaga, sobre la localidad actual se levanta un oppidum de 5,5 ha que es sin duda alguna una ciudad, que identifiqué con Lutiaka, diferenciándolo de la Lutia citada por Apiano, (pp. 307-308 de mi libro). Pero en esta diferenciación tomé los datos de 600 estadios de Apiano como si fueran un texto preciso y exacto. Ahora pienso que las fuentes escritas cuando dan cifras dan una información aproximada, y no exacta, por lo que pienso que la cita puede hacer referencia a Lutiaka = Lutia, que estaría a unos 900 estadios de Numancia, al fin y al cabo tal como se daban las referencias en la antigüedad 600 o 900 son reducciones de algo que está a una distancia aproximada. Fita 1883, pp. 35-45 y 48, Schulten 1937, p. 80, Sánchez-Lafuente 1995, p. 201, Burillo 2008, pp. 234 y 307-308.

83 Apiano recogió que ante la solicitud de ayuda para los situados numantinos durante la tercera y última guerra de Numancia, en Lutia, que era una ciudad opulenta que distaba de los numantinos trescientos estadios, allí los jóvenes tomaron partido a favor de los numantinos y empujaron también a la ciudad a una alianza con ellos, pero los ancianos los delataron en secreto a Escipión. Y cuando Escipión se enteró en la octava hora lanzó su ataque de forma inmediata con el mayor número que pudo de tropas ligeras y al amanecer, tras haber rodeado Lutia con guarniciones, exigió la entrega de los líderes de los jóvenes. Y cuando le dijeron que habían salido huyendo de la ciudad, proclamó mediante heraldo que arrasaría la ciudad si no conseguía capturar a estos hombres. Los de Lutia, entonces, llenos de temor, se los entregaron, alcanzando hasta un número de cuatrocientos hombres. Y él les cortó las manos y retiró sus guarniciones, y poniéndose de nuevo a la carrera, al amanecer del día siguiente se encontraba en su campamento, (Apiano VI 94).

${ }^{84}$ Ciprés expuso que le resultaba difícil asumir que Livio asimilara la juventud guerrera de los celtíberos, Celtiberum iuuentutem, (Livio XXIV 49, 7), con la iuuentus que, según él, debió existir en la antigua Roma. Ciprés 2006, p. 105. 
caso número de ciudades $^{85}$, señalando además que cuando Polibio afirma que Tiberio Graco destruyó trescientas de sus ciudades [celtíberas, en 179], Posidonio se burla y afirma que con ello dicho individuo pretendía congraciarse con Graco, llamando ciudades a las torres fortificadas, como en los desfiles triunfales, (Estrabón III 4, 13). Datos que coinciden con el hecho de que parte de los celtíberos, al menos los lusones, fueran trashumantes y que, por otra parte y según los lingüistas, el celtibérico también sería una lengua celta y, por tanto, de origen indoeuropeo, pero muy arcaica y menos evolucionada que la que hablaban otros celtas coetáneos suyos en otras partes de Europa ${ }^{86}$.

\section{CONCLUSIONES}

Tras la consecución del tratado del Ebro, los celtíberos quedaron en el área de influencia de los cartagineses y sometidos a éstos, por eso Aníbal no tuvo necesidad de someterlos cuando comenzó sus preparativos para conquistar Sagunto, como paso previo para su fallido intento de conquistar Roma.

La revisión de las referencias a los celtíberos y a Celtiberia en el relato que hizo Tito Livio de la segunda Guerra Púnica nos ha permitido concluir que fueron tres las formas de cooperación de los celtíberos con los romanos en su lucha contra los cartagineses: (1) sometidos a un estado extranjero más avanzado y potente, por medio de las condiciones acordadas a través de sus embajadores diplomáticos, incluyendo la entrega de rehenes como aval de cumplimiento del correspondiente pacto acordado, (2) como mercenarios al servicio del ejército de otro estado y actuando donde éste lo requiriera, dentro y fuera de la península lbérica, y (3) de buena voluntad, en agradecimiento por la devolución de los rehenes que les habían tomado los cartagineses.

Los celtíberos mantuvieron estos tres tipos de cooperación con los romanos y, además, en el orden expuesto. Eso sí, sin salir del ámbito geográfico de la penín-

\footnotetext{
85 A excepción de las importantes y potentes ciudades bajo dominio celtíbero pero ubicadas fuera de Carpetania, como por ejemplo Contrebia [Cárbica], Ercávica, Alces, Munda y Cértima que Livio citó al relatar el final de la expansión celtíbera en esta región y en otras aún más meridionales. Olcoz y Medrano 2011, en prensa.

86 Jordán recogió que se considera que el celtibérico es un dialecto arcaico. Entendiendo aquí por arcaico, que se trata de una lengua que dentro de su familia ha conservado más arcaísmos que otras. Es más, parece que se trata de la lengua celta con más arcaísmos, de la que se tiene conocimiento actualmente. Si bien, debemos añadir que, además, las acuñaciones de monedas celtibéricas en signario ibérico nororiental se venía considerando que fueron emitidas con posterioridad a 178, según Domínguez, entre otros, aunque recientemente hemos propuesto que podrían ser incluso posteriores a 167 a. C. Así como también aportar el dato acerca de que el epígrafe celtibérico no monetal más antiguo que se conoce como procedente de un yacimiento arqueológico conocido, procede de la ubicación más antigua de sekaiza - Ségeda (Mara, Zaragoza) y data de antes de 153 a. C. (siendo esta ceca, junto con la de arekoratas, las más antiguas de Celtiberia, como recordó Burillo). Concretamente, según de Hoz, se trata del posible nombre de persona, aresinu o aresiou, inscrito en una fusayola de cerámica, esto es en un objeto de uso cotidiano, como es el caso de una pesa de telar. Domínguez 1979, pp. 193-195 y 293-294, de Hoz 2003-2004, pp. 399-405, Jordán 2004, p. 52, Burillo 2008, p. 282 y Olcoz y Medrano 2011, en prensa.
} 
sula Ibérica pues su misión fue la de apoyar a los romanos en su guerra contra los cartagineses. Mientras que con éstos, sólo tenemos constancia de que los celtíberos mantuvieran las dos primeras y que, además lo hicieron en la península lbérica, en la Itálica y en el norte de África. Finalmente, en su interacción con el resto de los indígenas hispanos, durante la segunda Guerra Púnica, los celtíberos sólo apoyaron a los sublevados ilergetes en sus dos campañas consecutivas en Sedetania, como reacción a la incursión y ataque que los romanos hicieron en Celtiberia el año anterior, rompiendo así los acuerdos bilaterales que debían existir entre celtíberos y romanos.

Inicialmente y mientras cartagineses y romanos sometieron a los celtíberos de forma consecutiva y también, con cierta intermitencia, dato éste que no se suele tener en cuenta a la hora de considerar el proceso de la romanización de la península Ibérica, ambos estados emplearon la vía diplomática para someter al estado celtíbero y no la militar. Sin embargo, la evolución de la segunda Guerra Púnica también llevó a los cartagineses a contratar los servicios de los celtíberos como mercenarios, solución que imitaron los romanos de forma extraordinaria, por primera vez en su historia y con no muy buenos resultados.

Los datos conocidos sobre los lugares en los que los celtíberos entraron en batalla aportan información valiosa acerca de la capacidad de convocatoria de sus jóvenes príncipes guerreros y de la movilidad de sus tropas para presentarse con ejércitos multitudinarios allí donde fueron requeridos. Así, nos consta que lo hicieron al servicio de los cartagineses en lugares tan alejados de Celtiberia como Italia o el norte de África, mientras que al de los romanos le sirvieron sólo cerca de la costa mediterránea, tanto al norte del Ebro, como en la cabecera del Guadalquivir. Si bien es verdad que cuando los celtíberos decidieron acompañar a los pueblos hispanos sublevados bajo las órdenes de Indíbil y Mandonio, sólo lo hicieron en la vecina Sedetania, aliada de los romanos, y como reacción al hecho de que, poco antes, hubieran sido éstos quienes les hubieran atacado en la propia Celtiberia por primera y única vez durante la segunda Guerra Púnica. Por lo que el comportamiento bélico defensivo y su capacidad de aliarse o de someterse a Roma, antes y después de este acontecimiento, de forma similar a como antes lo hicieron los celtíberos con los cartagineses, no se parece en nada a su capacidad para llevar la ofensiva guerrera allí donde fuera necesario y sin que su teatro de operaciones tuviera ninguna vinculación con Celtiberia. Región de la península lbérica que parece seguir estando donde tradicionalmente se ha venido ubicando, esto es, en la margen derecha del Ebro, entre el valle del Jalón, la cuenca alta del Duero y, seguramente, las cercanías de las fuentes del Tajo.

Celtiberia era entonces un estado territorial gestionado como una coalición estable de gentilidades o clanes, cada uno de las cuales estuvo regido por un príncipe guerrero, eligiendo éstos a uno de ellos para que ejerciera como caudillo de toda la coalición. Es posible que esta organización fuera sólo la dominante en tiempos de guerra, que son los únicos que nos han llegado entrelazados en los relatos de la segunda Guerra Púnica y de las posteriores campañas bélicas que condujeron al sometimiento militar de Celtiberia por parte de los romanos, y que también existiera un senado de notables no guerreros cuyo papel fuera más importante en 
tiempos de paz, de ahí que éste hubiera pasado más desapercibido en las citadas fuentes. Aunque creemos que éste bien pudo aparecer con posterioridad a la desmembración del estado celtibérico y al fomento que los romanos hicieron para que se desarrollaran ciudades estado sometidas a ellos e imitando su estilos de gobierno, como parte de su proceso colonizador de Hispania.

Finalmente, podemos concluir diciendo que a la vista de los resultados expuestos acerca de los datos geográficos y de los relacionados con el comportamiento de los celtíberos y sus relaciones con cartagineses, romanos y diversos pueblos hispanos, la revisión de la información suministrada por Tito Livio, en su relato acerca de la segunda Guerra Púnica, ha resultado de gran valor. Pues nos ha cambiado considerablemente la percepción e interpretación de cómo fue el sometimiento de Celtiberia y de los celtíberos que cartagineses y romanos llevaron a cabo y de cuál fue la participación del estado celtíbero en la segunda Guerra Púnica. A pesar de que, hasta ahora, este período de la Historia no se hubiera abordado así en los estudios acerca de los celtíberos y de Celtiberia.

\section{Anexo I: Índice cronológico de la presencia celtíbera en la segunda Guerra Púnica}

218 a. C.

- Aníbal, en la península ltálica, promete a sus tropas mejores resultados que los logrados en Celtiberia.

217 a. C.

- Jinetes celtíberos sirven como auxiliares de Aníbal en Italia debido a que son aliados con rehenes.

- El estado celtíbero envía embajadores, se somete a los romanos y entrega rehenes

- Los celtíberos, a solicitud de los romanos atacan a los cartagineses al Norte del Ebro (territorio de ilergavones)

213 a. C.

- Los celtíberos, mercenarios de los cartagineses, pasan a ser mercenarios de romanos

212 a. C.

- Los celtíberos, mercenarios de los romanos, abandonan a Gneo Cornelio Escipión, sobornados por los cartagineses

- Los celtíberos abandonan su alianza con los romanos y vuelven a ser aliados de los cartagineses

210 a. C.

- Los celtíberos vuelven a someterse a los romanos, tras la toma de Cartagena.

209 a. C.

- Asdrúbal se lleva mercenarios celtíberos a Italia

207 a. C. 
- Hannón recluta mercenarios en Celtiberia

- Silano realiza la primera incursión romana en Celtiberia y derrota a cartagineses y celtíberos

206 a. C.

- Los cartaginenses reclutan mercenarios celtíberos y son derrotados por Lucio Marcio

- Los celtíberos consideran roto el pacto con los romanos y se unen a la sublevación de Indíbil

- Escipión acaba con la sublevación de forma magnánima: perdón y pago de una multa

- Los celtíberos sometidos otra vez a Roma

203 a. C.

- Celtíberos, mercenarios de los cartagineses, derrotados en el Norte de África por los romanos

201 a. C.

- Fin de la segunda Guerra Púnica y de la primera Guerra de Roma en Hispania

\section{Anexo II: Textos de Tito Livio acerca de los Celtíberos durante la segunda Guerra Púnica}

A continuación se presentan los pasajes de la obra de Tito Livio, según la traducción de Villar ${ }^{87}$, en los que se cita explícitamente a los celtíberos o Celtiberia.

\section{Livio XXI 43, 8-10}

[218 a. C.] [Arenga de Aníbal]. Bastante tiempo lleváis corriendo detrás del ganado de los desolados montes de Lusitania y Celtiberia sin ver ningún pago a tantos trabajos y peligros; ya es hora de que hagáis una campaña abundante y fructífera y recibáis una recompensa cumplida por vuestro trabajo tras recorrer una travesía larga por medio de tantos montes y ríos y tantos pueblos en armas.

\section{Livio XXI 57, 5}

[218/217 a. C.] [Roma: Alarma, elecciones consulares. La acción en Placencia y Victúmulas (Italia). Marcha de Aníbal a Etruria]. Pero ni siquiera el campamento de invierno de los romanos estaba tranquilo, al andar merodeando por todas partes los jinetes númidas, y también los celtíberos y lusitanos cuando aquéllos encontraban alguna especial dificultad.

\section{Livio XXII 21, 7-8}

[217 a. C.] [Indíbil y Mandonio. Los rehenes de Sagunto]. Los celtíberos, que habían enviado como embajadores a los principales de su país y habían entregado rehenes a los romanos, instigados por un mensajero enviado por Escipión empuñan las armas e invaden con un fuerte ejército la zona de dominio cartaginés. Toman tres plazas al asalto, a continuación

87 Villar 1993a y 1993b. 
libran con éxito dos combates contra el propio Asdrúbal [al norte del Ebro], dando muerte a quince mil enemigos, y capturan a cuatro mil, junto con un gran número de enseñas militares.

\section{Livio XXII 22, 1-5}

[217 a. C.] Estando así las cosas en Hispania llega a su provincia Publio Escipión, enviado por el senado con una prórroga en el mando tras su consulado, con treinta naves largas y ocho mil soldados, transportando una gran cantidad de provisiones. Esta flota, de enormes proporciones por la cantidad de naves de carga, y que fue avistada a distancia con gran alegría de compatriotas y aliados, desde alta mar puso proa al puerto de Tarragona. Desembarcadas allí las tropas, Escipión fue a reunirse con su hermano [Gneo], y a partir de entonces dirigían las operaciones bélicas de común acuerdo. Mientras los cartagineses están absorbidos por la guerra celtibérica, ellos cruzan el Ebro sin vacilar, y no encontrando ningún enemigo siguen su marcha en dirección a Sagunto, porque se hablaba de que se encontraban allí los rehenes de toda Hispania entregados por Aníbal, custodiados en la ciudadela por una guarnición no muy importante. Esta alianza era lo único que retenía a todos los pueblos de Hispania proclives a una alianza con Roma, por temor a pagar las culpas de su defección con la sangre de sus hijos.

\section{Livio XXIV 49, 7-8}

[213 a. C.] [En África, el rey (Númida) Sífax se alía con los romanos. Tranquilidad en Hispania]. En Hispania no ocurrió nada digno de mención salvo el hecho de que los generales romanos atrajeron a su lado a la juventud celtíbera por la misma paga que habían convenido con los cartagineses, y enviaron a Italia más de trescientos hispanos de la alta nobleza para que tratasen de atraerse a los paisanos suyos que servían como auxiliares en el ejército de Aníbal. De lo ocurrido aquel año en Hispania sólo una cosa es digna de mención: el hecho de que estos celtíberos fueron los primeros mercenarios que hubo en el ejército romano.

\section{Livio XXV 32, 1-10}

[212 a. C.] [Hispania: Los Escipiones dividen sus fuerzas. Asdrúbal pacta la inhibición de los celtíberos]. Aquél mismo verano, en Hispania donde en casi dos años no había tenido lugar ninguna acción especialmente destacable y la guerra se desarrollaba más a base de estrategia que de enfrentamientos armados, los generales romanos salieron de los cuarteles de invierno y unieron sus tropas. Se reunió entonces el consejo y todas las opiniones coincidieron en que, si bien hasta entonces lo único que se había hecho era retener a Asdrúbal que pretendía pasar a Italia, era ya tiempo de dar los pasos para poner fin a la guerra en Hispania; estaban convencidos, además, de que se habían reunido fuerzas suficientes para ello con la incorporación a filas de veinte mil celtíberos efectuada aquel invierno. Los ejércitos cartagineses eran tres. Asdrúbal, hijo de Gisgón, y Magón, que habían unido sus tropas, se encontraban a unos cinco días de marcha de los romanos. Más cerca estaba Asdrúbal el hijo de Amilcar, que tenía su ejército junto a una ciudad llamada Amtorgis. Los generales romanos querían sorprender primero a éste, y esperaban que hubiera fuerza más que suficiente para ello; les preocupaba únicamente que el otro Asdrúbal y Magón se alarmaran con su derrota, se retiraran a los montes y bosques inaccesibles y prolongaran la guerra. Pensaron, pues, que lo mejor era dividir las tropas en dos cuerpos para abarcar toda Hispania al mismo tiempo en su campaña y se las repartieron de esta forma: Publio Cornelio mandaría dos terceras partes de los efectivos romanos y aliados contra Magón y Asdrúbal, y Gneo Cornelio, con un tercio del antiguo ejército, al que se unirían los celtíberos, dirigiría la campaña contra Asdrúbal Barca. Los dos generales con los dos ejércitos emprendieron la marcha al mismo tiempo yendo en cabeza los celtíberos, y acamparon cer- 
ca de la ciudad de Amtorgis a la vista del enemigo, separados de él por un río. Gneo Escipión se quedó allí con las tropas que antes hemos dicho y Publio Escipión partió hacia el objetivo bélico que se le había asignado.

\section{Livio XXV 33, 1-7}

Asdrúbal, cuando se dio cuenta de que en el campamento había un ejército romano muy reducido que cifraba todas sus esperanzas en las tropas auxiliares de los celtíberos, buen conocedor de la absoluta deslealtad de los pueblos bárbaros y especialmente de la de todos aquellos entre los que llevaba tantos años de campaña, llegó a un acuerdo con los jefes celtíberos a través de conversaciones secretas - la comunicación era fácil al estar lleno de hispanos ambos campamentos- para que a cambio de una fuerte recompensa retiraran de allí sus tropas. No les pareció, por una parte, una acción monstruosa -no se trataba, en efecto, de que volviesen sus armas contra los romanos-, y por otra parte se les ofrecía, por no hacer la guerra, una suma suficiente como para hacerla, y además resultaban en general agradables tanto el propio descanso como la vuelta a casa y el placer de ver a los suyos y sus cosas. De modo que no resultó más difícil convencer a la tropa que a sus jefes. Aparte de que ni siquiera tenían el temor de que los romanos, tan pocos en realidad, los retuvieran por la fuerza. La verdad es que los jefes romanos deberán tener siempre cuidado con esto y servirles de advertencia estos precedentes, de suerte que no confíen en las tropas auxiliares extranjeras hasta el punto de tener en los campamentos un contingente inferior de fuerzas de su propia patria. Los celtíberos desclavaron inesperadamente sus enseñas y se marcharon, y cuando los romanos les preguntaron la razón y les rogaron encarecidamente que se quedasen, su única respuesta fue que los reclamaba una guerra intestina. Escipión, dado que no era posible retener a los aliados ni con ruegos ni a la fuerza, en vista de que sin ellos estaba en inferioridad con respecto al enemigo y que no podía reunirse de nuevo con su hermano ni tenía a su alcance ninguna otra vía de solución, decidió retroceder cuanto le fuera posible, poniendo el mayor cuidado en no enfrentarse en ningún momento en terreno llano con el enemigo, que había cruzado el río e iba pisándole los talones en su retirada.

\section{Livio XXVI 41, 20-22}

[210 a. C] [En Hispania, Escipión inicia una marcha sobre Cartagena]. Maltratados por ellos [los cartagineses], sus aliados imploran vuestra [de los romanos] protección por medio de embajadas; tres generales, mal avenidos hasta el extremo casi de traicionarse unos a otros, desmembraron el ejército en tres cuerpos tirando de ellos en direcciones completamente opuestas. Cae sobre ellos la misma mala suerte que antes nos agobió a nosotros, pues son abandonados por sus aliados igual que antes nosotros por los celtíberos, y han dividido las fuerzas, cosa que significó la ruina para mi padre y mi tío; ni las desavenencias internas les permitirán unirse, ni podrán resistírsenos por separado.

\section{Livio XXVI 50, 1-14}

[Episodio de los rehenes hispanos (de Cartagena)]. Después los soldados conducen a su presencia a una prisionera, una muchacha joven de tan notable belleza que atraía a su paso todas las miradas. Escipión le preguntó de dónde procedía y quienes eran sus padres, y entre otras cosas se enteró de que era la prometida de un príncipe celtíbero, un joven llamado Alucio. Mandó, pues, a buscar inmediatamente a su tierra a sus padres y a su prometido, y como entretanto se enteró de que éste moría de amor por su prometida, en cuanto llegó se dirigió a él escogiendo las palabras con más cuidado que cuando les habló a los padres. "Te hablo como lo hace un joven a otro, para que haya menos miramientos en nuestra conversación. Tu prometida fue hecha prisionera, y 
conducida a mi presencia por mis soldados; he oído que la amas profundamente, y su belleza lo hace creíble; como también yo, si tuviera libertad para disfrutar de los placeres de la juventud y sobre todo de un amor honesto y legítimo y no me absorbiesen los asuntos del Estado, desearía que se fuese indulgente conmigo por amar demasiado a mi prometida, ya que está en mi mano quiero favorecer tu amor. A tu prometida se le ha dispensado aquí a mi lado un trato tan respetuoso como si estuviera en casa de sus padres, tus futuros suegros; te la hemos preservado para poder hacerte un regalo respetado y digno de ti y de mí. La única recompensa que pido a cambio de este presente es que seas amigo del pueblo romano, y si me consideras un hombre de bien como ya antes sabían estas gentes que lo eran mi padre y mi tío, has de saber que en Roma hay muchos como nosotros y no se puede citar hoy en todo el mundo ningún otro pueblo al que puedas desear menos como enemigo tuyo y de los tuyos o preferir como amigo". El joven, transido de alegría y de confusión al mismo tiempo, cogiendo la diestra de Escipión invocaba a todos los dioses para que lo recompensasen en su lugar, puesto que en modo alguno tenía los recursos proporcionados a lo que él sentía y Escipión se merecía de él; fueron llamados entonces los padres y parientes de la doncella; éstos, ya que se les devolvía gratis la muchacha para cuyo rescate habían traído una cantidad bastante considerable de oro, comenzaron a rogar a Escipión que se lo aceptase como regalo asegurándole que no se lo iban a agradecer menos que el hecho de haberles devuelto intacta a la muchacha. Escipión dijo que lo aceptaría, ya que se lo pedían con tanta insistencia, hizo que lo depositaran a sus pies y llamando a su presencia a Alucio le dijo: «Éste es mi regalo de boda, para añadir a la dote que recibirás de tu suegro", y le mandó coger el oro y quedarse con él. Feliz por el honor y el regalo que se le hacía, marchó a su tierra, donde abrumó a sus paisanos hablándoles de los méritos de Escipión elogiosamente: había llegado un joven que se asemejaba mucho a los dioses, que lo conquistaba todo o bien con las armas o bien a base de bondad y generosidad. Hizo, pues, una leva entre sus súbditos y a los pocos días volvió junto a Escipión con mil cuatrocientos jinetes escogidos.

\section{Livio XXVIII 1, 1-9}

[207 a. C.] [En Hispania, Marco (Julio) Silano vence a los Celtíberos]. Cuando parecía que la guerra había basculado hacia Italia con el paso de Asdrúbal, en la misma medida en que había perdido peso en Hispania, de pronto se rompieron otra vez aquí las hostilidades igual que antes. En aquella época las Hispanias estaban ocupadas por los romanos y los cartagineses de la forma siguiente: Asdrúbal, el hijo de Gisgón, se había retirado hasta los confines del Océano, a Cádiz; la costa del Mediterráneo y casi toda la zona este de Hispania estaba bajo el dominio de Escipión y de Roma. Un nuevo general, Hannón, que había cruzado desde África con un nuevo ejército para reemplazar a Asdrúbal Barca y se había unido a Magón, en poco tiempo había armado un gran número de hombres en Celtiberia, que está situada entre los dos mares; Escipión envió contra él a Marco Silano con no más de diez mil hombres de a pié y quinientos de a caballo. Silano forzó cuanto pudo la marcha y, a pesar del obstáculo que suponían las rutas accidentadas y los pasos encajonados entre espesos bosques, como ocurre en buena parte de Hispania, se adelantó no sólo a los mensajeros sino incluso a los rumores de su llegada, y guiado por desertores de la propia Celtiberia llegó hasta el enemigo. Por informes de estos guías supo, cuando estaban a unas diez millas del enemigo, que había dos campamentos junto a la ruta que seguían; que los celtíberos, un ejército nuevo de más de nueve mil hombres, tenían su campamento a la izquierda, y los cartagineses el suyo a la derecha; que este estaba adecuadamente defendido con puestos de guardia, con centinelas y con todas las medidas regulares de seguridad militar, y que en el otro había indisciplina y falta de precauciones como es propio de bárbaros y de novatos que estaban menos en guardia por el hecho de encontrarse en su propia tierra. 
Silano consideró que había que atacar éste primero y ordenó dirigir la marcha hacia la izquierda lo más posible para evitar ser avistado desde algún puesto de guardia cartaginés. Envió por delante exploradores y él se dirigió directamente hacia el enemigo acelerando la marcha.

\section{Livio XXVIII 2, 1-14}

Estaban casi a tres millas y el enemigo no había detectado su presencia, pues el terreno era accidentado y les servían de cobertura unas colinas pobladas de arbustos. Allí, en un valle profundo y no visible por consiguiente, dio orden a sus hombres de hacer alto y tomar alimento. Entretanto llegaron los exploradores confirmando lo dicho por los desertores. Entonces los romanos depositan allí mismo los bagajes, empuñan las armas y avanzan en formación de batalla. Estaban a una milla de distancia cuando el enemigo los avistó y comenzó inmediatamente la actividad; también acudió al galope desde su campamento Magón al iniciarse los gritos y el tumulto. En el ejército celtibérico había cuatro mil hombres armados con escudo largo y doscientos jinetes. Situó en primera línea esta legión regular — que venía a ser la fuerza principal-; el resto, infantería ligera, lo dejó de reserva. Cuando los sacaba del campamento formados en este orden y apenas habían cruzado la empalizada, los romanos lanzaron sobre ellos sus jabalinas. Los hispanos se agacharon ante los dardos disparados por el enemigo y después se reincorporaron para disparar a su vez; los romanos, en formación cerrada como de costumbre, recibieron los dardos juntando los escudos y después se inició el cuerpo a cuerpo combatiendo a espada. Pero lo accidentado del terreno hacía inútil la rapidez de los celtíberos, que suelen combatir a base de carreras sucesivas, mientras que para los romanos, habituados a combatir a pie firme, esta circunstancia no era desfavorable, con la salvedad de la escasez de espacio y los arbustos que crecían aquí y allá rompían la continuidad de las filas y se veían obligados a combatir de uno en uno o de dos en dos, como en duelos por parejas. Precisamente lo que obstaculizaba la huida de los enemigos los dejaba expuestos al degüello como maniatados; muertos ya casi todos los celtíberos armados de escudo, eran abatidas y exterminadas las tropas ligeras y los cartagineses que habían venido a ayudar desde el otro campamento. No más allá de los dos mil hombres de infantería y toda la caballería huyeron con Magón apenas iniciado el combate. Hannón, el otro general, fue capturado vivo junto con los que habían llegado al final, cuando la batalla estaba ya perdida. Casi toda la caballería y los veteranos de infantería que habían seguido a Magón en su huida llegaron a los nueve días al lado de Asdrúbal, a la circunscripción de Cádiz. Los reclutas celtíberos se dispersaron por los bosques vecinos y de allí huyeron a sus distintos lugares de residencia.

Tan oportuna victoria no sofocó la conflagración bélica que se había desencadenado, es cierto, pero sí ahogó el germen de la guerra que habría sobrevenido si los cartagineses hubieran tenido la posibilidad de levantar en armas a otros pueblos después de sublevar a los celtíberos. Por eso Escipión felicitó vivamente a Silano y, abrigando la esperanza de poner fin a la guerra si él mismo no lo frustraba por andar remiso, marchó contra Asdrúbal, al último confín de Hispania, que era lo que quedaba de la guerra.

\section{Livio XXVIII 24, 4}

[206 a. C.] [Motín en el ejército al caer enfermo Escipión]. Mandonio e Indíbil, que se habían hecho ilusiones de dominar Hispania una vez expulsados de ella los cartagineses, como nada se había desarrollado de acuerdo a sus expectativas, concitaron a sus coterráneos - que eran los lacetanos-, sublevaron a la juventud de los celtíberos y devastaron con saña el territorio de los suesetanos y sedetanos, aliados del pueblo romano.

\section{Livio XXVIII 42, 8}


[205 a. C.] [Discurso de Fabio en contra del plan de Escipión]. «¿O es que confías en Sífax y en los númidas? Bástete con haber confiado una vez; no siempre sale bien la temeridad, y el engaño se gana la credibilidad en las cosas poco importantes primero, para engañar sacando gran provecho cuando merece la pena. Quienes primero envolvieron a tu padre y tu tío no fueron los enemigos con las armas sino sus aliados los celtíberos con una trampa; tú mismo no corriste tanto peligro con Magón y Asdrúbal, generales enemigos, como con Indíbil y Mandonio, acogidos a tu protección.

\section{Livio XXX 7, 10}

[203 a. C.] [Cartago organiza la resistencia. Derrota de Sífax en los Llanos Grandes]. Además, los emisarios brindaban una perspectiva que se había abierto muy a tiempo: en las proximidades de la ciudad de Oba se habían encontrado con cuatro mil celtíberos, una juventud escogida alistada en Hispania por sus reclutadores, y por otra parte se iba a presentar Asdrúbal de un momento a otro con un contingente de tropas muy considerable.

\section{Livio XXX 8, 6 y 8}

Sífax y Asdrúbal, con los númidas situados frente a la caballería itálica y los cartagineses frente a Masinisa, metieron en el centro de la formación a los celtíberos haciendo frente a los legionarios. Así formados, se lanzan al ataque. En la primera carga fueron rechazadas a la vez las dos alas enemigas, tanto los númidas como los cartagineses, pues ni los primeros, campesinos en su mayoría, resistieron a la caballería romana, ni los cartagineses, que a su vez eran soldados bisoños, pudieron resistir a Masinisa, aún más terrible después de su reciente victoria. A pesar de tener ambos flancos al descubierto, la línea formada por los celtíberos aguantaba a pie firme porque la huida no les ofrecía ninguna expectativa de salvación en unos parajes desconocidos ni tenían esperanzas de perdón por parte de Escipión, contra el que habían ido a África a combatir con armas mercenarias a pesar de lo bien que se había portado con ellos y con su pueblo. Por eso, rodeados de enemigos por todas partes, se obstinaban en morir cayendo uno sobre otro; y como todos estaban vueltos contra ellos, Sífax y Asdrúbal tuvieron tiempo suficiente para huir. La noche sorprendió a los vencedores, cansados por una matanza que había durado más que el combate.

\section{BIBLIOGRAFÍA}

BELLÓN RUIZ, J. P., WIÑA GARCERÁN, L., GÓMEZ CABEZA, F., LOZANO OCAÑA, G., GUTIÉRREZ SOLER, L. M. ${ }^{a}$, RUIZ RODRÍGUEZ,, SÁNCHEZ VIZCAÍNO, A., RUEDA SABATER, C., MOLINOS MOLINOS, M. y GARCÍA LUQUE, M. ${ }^{a}$ A., 2004: Baecula: Arqueología de una batalla, Proyectos de investigación (2002-2003), Universidad de Jaén, Gálvez del Postigo, A. (Coord.), Jaén, pp. 11-66.

BLÁZQUEZ DELGADO-AGUILERA, A., 1894: Las costas de España en época romana, Boletín de la Real Academia de Historia, n. 24. Madrid, pp. 385-430.

BLÁZQUEZ MARTÍNEZ, J. M. a , 1962: La expansión celtibérica en Bética, Carpetania, Levante y sus causas (Siglos III-II a. C.), Celticum, n. 3, Actes du second colloque international d'études gauloises, celtiques et protoceltiques, Rennes, pp. 409-428.

BURILLO MOZOTA, F., 2008: Los Celtíberos. Etnias y estados, Barcelona.

CAPALVO LIESA, A., 1996: Celtiberia: Un estudio de fuentes literarias antiguas, Zaragoza.

CIPRÉS TORRES, M. ${ }^{a}$ P., 1990: Sobre la organización militar de los celtíberos: La ivventvs, Veleia, n. 7, Vitoria, pp. 173-187.

CIPRÉS TORRES, M. ․ P., 1993: Celtiberia: La creación geográfica de un espacio provincial, Ktéma, n. 18, Estrasburgo, pp. 259-291. 
CIPRÉS TORRES, M. a P., 2006: Sobre la organización militar de los celtíberos: La invención de una geografía de la península Ibérica. I. La época republicana, Actas del Coloquio Internacional celebrado en la Casa de Velázquez de Madrid entre el 3 y el 4 de marzo de 2005, Cruz Andreotti, G., Le Roux P. y Moret, P. (Eds.), Madrid, pp. 177-197.

DOMÍNGUEZ ARRANZ, A., 1979, Las cecas ibéricas del valle del Ebro. Zaragoza.

FITA COLOMÉ, F., 1883: Lámina Celtibérica de Bronce, hallada en el Término Municipal de Luzaga, Partido Judicial de Sigüenza, Boletín de la Real Academia de la Historia, t. II, n. 6, Madrid, pp. 35-45 y 48.

GÓMEZ ESPELOSÍN, F. J., 2006: Guerras Ibéricas. Aníbal. Apiano, Madrid.

GÓMEZ ESPELOSíN, F. J., 2007: Geografía de Iberia. Estrabón, Madrid.

HERNÁNDEZ VERA, J. A., 2003: Contrebia Leukade y la definición de un nuevo espacio para la segunda guerra púnica, Salduie, n. 3, Zaragoza, pp. 61-82.

HINOJO ANDRÉS, G. y MORENO FERRERO, I., 2000: Floro: Epítome de la Historia de Tito Livio, Madrid.

DE HOZ BRAVO, J., 2003-2004: Fusayola de Segeda, Kalathos, n. 22-23, Teruel, pp. 399405.

JORDÁN CÓLERA, C. B., 2004: Celtibérico, Zaragoza.

MARINER BIGORRA, S., 1968: Tito Livio: Ab Urbe Condita. Libro XXII, Madrid.

MORET, P., 2002-2003: Los monarcas ibéricos en Polibio y Tito Livio, Cuadernos de Prehistoria y Arqueología, n. 28-29, Madrid, pp. 23-34.

MUÑIZ COELLO, J., 1994b: Instituciones políticas celtas e ibéricas. Un análisis de las fuentes literarias, Habis, n. 25, Sevilla, pp. 91-105.

OLCOZ YANGUAS, S. y MEDRANO MARQUÉS, M. M.ㄹ, 2006: Tito Livio: Castra Aelia y el límite meridional del Ager Vasconum, antes y después de Sertorio, Navarra: Memoria e Imagen, Actas del VI Congreso de Historia de Navarra, v. I, n. 28-29, Madrid, pp. 55-75.

OLCOZ YANGUAS, S. y MEDRANO MARQUÉS, M. M. a, 2011: La expansión de los celtíberos, la conquista romana de Celtiberia y el final del estado federado de los celtíberos, en el relato de Tito Livio, en prensa.

PELEGRÍN CAMPO, J., 2004: Celtíberos en África: En torno a un episodio de la Segunda Guerra Púnica, Antiqua iuniora: En torno al Mediterráneo en la Antigüedad, Beltrán Lloris, F. (Ed.), Zaragoza, pp. 173-188.

PELEGRÍN CAMPO, J., 2005: Polibio, Fabio Píctor y el origen del etnónimo «Celtíberos», Gerión, v. 3, n.․ 1, Madrid, pp. 115-136.

PÉREZ VILATELA, L., 1991: llercavones, celtíberos y cartagineses en 218-217, Caesaraugusta, n. 68, Zaragoza, pp. 205-228.

PÉREZ VILATELA, L., 2000: Lusitania: Historia y etnología, Madrid.

QUESADA SANZ, F., 2003: La guerra en las comunidades ibéricas (C. 237-C. 195 a.C.: un modelo interpretaivo), Defensa y territorio en Hispania, de los Escipiones a Augusto: (Espacios urbanos y rurales, municipales y provinciales), Morillo Cerdán, A., Cadiou, F. y Hourcade, D. (Coords.), n. 68, Zaragoza, pp. 101-158.

SALINAS DE FRÍAS, M., 1983: La función del hospitium y la clientela en la conquista y romanización de Celtiberia, Studia Historica. Historia Antigua, n. 1, Salamanca, pp. 21-42.

SALINAS DE FRÍAS, M., 1986: Conquista y romanización de Celtiberia, Salamanca.

SÁNCHEZ ROYO, A., 1976: En torno al tratado del Ebro entre Roma y Asdrúbal, Habis, n. 7, Sevilla, pp. 75-110.

SÁNCHEZ SALOR, E., 1982: Orosio: Historias. Libros I-IV, Madrid.

SÁNCHEZ-LAFUENTE PÉREZ, J., 1995: Luzaga. Ciudad de la Celtiberia, Poblamiento Celtibérico. III Simposio sobre los celtíberos, Burillo Mozota (Coord.), Zaragoza, pp. 191201.

SANTOS YANGUAS, N. V., 1977: El tratado del Ebro y el origen de la Segunda Guerra Púnica, Hispania, v. 37, n. 136, Sevilla, pp. 269-298.

SCHULTEN, A., 1935: Las Guerras de 237-154 a. de J.C. Fontes Hispaniae Antiquae, n. 3, Barcelona. 
SCHULTEN, A., 1937: Las guerras de 154-72 a. de J. C. Fontes Hispaniae Antiquae, IV, Barcelona.

THOMPSON, E. A., 1967: The early germans, Oxford.

VILLA VIDAL, J. A., 1993a: Tito Livio. Historia de Roma desde su fundación. Libros XXI-XXV, Madrid.

VILLA VIDAL, J. A., 1993b: Tito Livio. Historia de Roma desde su fundación. Libros XXVI$X X X$, Madrid.

VILLA VIDAL, J. A., 1993c: Tito Livio. Historia de Roma desde su fundación. Libros XXXI$X X X V$, Madrid.

VILLA VIDAL, J. A., 1995: Tito Livio. Períocas. Períocas de Oxirrinco. Fragmentos. Julio Obsequente: Libro de los Prodigios, Madrid.

WALBANK, F. A., 1957: A Historical Commentary on Polybius, t. II, Oxford. 